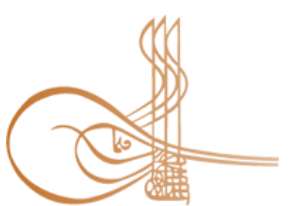

www.turkishstudies.net/social
Turkish Studies - Social Sciences

eISSN: 2667-5617

Research Article / Araştırma Makalesi

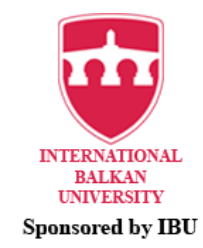

\title{
Avrupa Birliği Ülkelerinin İnovasyon Etkililik, Etkinlik ve Verimlilik Performanslarının Analizi
}

Analysis of Innovation Effectiveness, Efficiency and Productivity Performance of European Union Countries

\author{
Furkan Fahri Altıntaș*
}

\begin{abstract}
The concept of innovation is of great importance not only for businesses and other organizations, but also for countries. Because innovation concept has multiple network structure with science, art, technology, health and social dimensions, innovation can provide countries to develop and change according to the situation. The innovation performance of countries should be evaluated not only with the global innovation index values of the countries, but also with the innovation effectiveness, efficiency and productivity performances of the countries. Because it is important to provide optimal innovation performance within the framework of cost analysis in the relationships between innovation inputs and outputs. In this context, the primary purpose of the research is to determine the importance levels (weighting coefficients) of the components that make up the global innovation input and output subdirectories according to the European Union countries. The other aims of the research is to determine the innovation effectiveness, efficiency and productivity performance values of the European Union countries. Based on the findings, it has been determined that the most important innovation component according to the countries is the creative output. Again, according to the findings, the three countries with the highest innovation effectiveness are Sweden, the Netherlands and the UK, the three countries with the highest innovation efficiency are Slovakia Hungary and Luxembourg, and the three with the highest innovation productivity are Greece, Austria and Portugal. The research found that the rankings of innovation effectiveness, efficiency and productivity performance values of most countries are not consistent with each other. Therefore, this shows that the concepts of innovation effectiveness, effectiveness and productivity differ from each other.
\end{abstract}

\section{Structured Abstract: Introduction}

Since the concept of innovation is related to all dimensions that provide development and progress, the concept of innovation is very important for countries. In particular, thanks to innovation activities, countries can provide their economic development, growth, development and increase their welfare levels, quality of life and living standards. In addition, innovation can play an important role in ensuring the development of countries in the fields of culture, health, sports, science, technology, science, social and other fields. Therefore, countries should have a certain innovation performance in ensuring their development in various fields.

\footnotetext{
* Dr., Jandarma Genel Komutanlığı

Dr. Gendarmerie General Command

ORCID 0000-0002-0161-5862

furkanfahrialtintas@gmail.com

Cite as/ Atıf: Altıntaş, F.F. (2020). Avrupa Birliği ülkelerinin inovasyon etkililik, etkinlik ve verimlilik performanslarının analizi, Turkish Studies - $\quad$ Social, $15(5), \quad$ 2337-2361. https://dx.doi.org/10.47356/TurkishStudies.43678

Received/Geliş: 18 May/Mayıs 2020

Accepted/Kabul: 20 August/Ağustos 2020

Copyright (C) INTAC LTD, Turkey 
Countries need to know and recognize their innovation potential, capacity, abilities and shortcomings in order to carry out their innovation activities in a meaningful, effectiveness, efficiency and productivity manner. For this, countries need international criteria and indices that determine their innovation performance. Thus, with the knowledge of their own performances, countries can determine their superiority in innovation and the innovation issues that need to be developed in great detail. Accordingly, countries can build their innovation methods, strategies, management, practices and planning more robustly in subsequent innovation processes.

Countries also want to know the innovation performance of other countries. Because countries can cooperate with the other countries that have high innovation performance. Thus, countries can improve themselves on innovation issues. Therefore, countries complement each other by knowing their own shortcomings and superiorities in innovation. In this way, countries can contribute to the global economy, development and the development of innovation.

One of the criteria that determine the innovation performance of countries is the global innovation index. This index shows the global innovation performance of countries and the ranking of innovation performances on a country basis. Therefore, thanks to this index, innovation performances of countries can be compared.

In addition to the innovation performances of the countries, it is very important to measure innovation effectiveness, efficiency and productivity performances. In this way, the levels of achievement of innovation activities within the scope of innovation effectiveness of the countries, the level of achieving the right things about innovation or correct determination of the goals within the scope of innovation efficiency of the countries, and finally the right to do innovation works within the scope of innovation productivity of countries can be determined. Thus, the innovation performances of the countries can be evaluated multidimensionally, so that the countries will be able to identify the effects of the input and output components in ensuring innovation performance.

\section{Purpose and Method}

The data set of the study is composed of the data of the global innovation index components of the European Union countries (28 countries) for 2019 (latest report). The research has 4 purposes. The mathematical methods applied to determine these 4 goals and 4 goals are presented below as items

-To determine the importance of innovation components according to countries by Entropy method.

-To determine the innovation effectiveness performance values of the countries.

-To determine the innovation efficiency performance values of the countries with the OCRA method.

-To determine the innovation efficiency performance values of the countries with the EATWIOS method.

Although European Union countries constitute only $7 \%$ of the world population, it constitutes approximately $26 \%$ of the world GDP (www.izto.org.tr). Therefore, the smallest change in the strategies, methods, management, techniques and practices of innovation in European Union countries can affect the world economy and innovation activities of other countries. Consequently, because the innovation activities of the European Union countries are considered to be important in this respect, European Union countries innovation performances were investigated in the study.

\section{Findings and Discussion}

The importance degree of innovation components by countries are listed as creative output, infrastructure, institutions, market sophistication, knowledge and technology output, business sophistication and human capital and research. According to the European Union countries, the importance degree of innovation components has been determined to be very close to each other. This situation has been assessed that the European Union countries give equal importance to the innovation components in general and accordingly the innovation components complement each other according to the European Union countries. In the research, it was determined that the average importance degree of the innovation output components by countries is higher than the average importance degree of the innovation input components. Therefore, it has been evaluated that European Union countries have completed their innovation foundations (inputs) and 
accordingly, European Union countries have concentrated more on result-oriented (outputs) innovation activities than cause-oriented (inputs) innovation activities. This situation also shows that European Union countries want to benefit from the added value and positive results that they will create innovation.

When the innovation effectiveness values of the countries are evaluated, the top three countries with the highest innovation effectiveness are Sweden, Netherlands and England. it can be evaluated that countries with high innovation effectiveness perform more efficiently than other countries in their analysis of which innovation input/inputs will provide which innovation output/outputs more optimally.

The top three countries with the highest innovation efficiency performance values of the countries were identified as Slovakia, Hungary and Luxembourg. It is evaluated that the countries with high innovation efficiency, the correct determination of the innovation objectives and the level of doing the right things about innovation are higher than the other countries. Thus, this shows that countries with high innovation efficiency know their innovation potential and abilities more than other countries.

According to the findings, it is determined that the top 3 countries with the highest productivity performance values of the countries are Greece, Austria and Portugal. It can be evaluated that the countries with high innovation productivity are at the level of achieving innovation goals and doing the right job in innovation compared to other countries. Therefore, it can be thought that countries with high innovation productivity are more consistent with their innovation planning and innovation practices compared to other countries.

\section{Conculusions}

Separately, the results of France's innovation effectiveness and productivity, Croatia's innovation efficiency and productivity, and Italy's efficiency and effectiveness performance rankings are the same. Except for the mentioned countries, the rankings of innovation effectiveness, efficiency and productivity performance values of other countries are determined to be different from each other. Therefore, the rankings of innovation effectiveness, efficiency and productivity values of the countries included in the research show that the concepts of effectiveness, efficiency and productivity are related to each other, but the concepts in question are different from each other.

\section{Suggestions}

This study is a dataset for researchers within the scope of determining the innovation effectiveness, efficiency, productivity performance values of the 28 member countries of the European Union for 2019 and the importance levels (weighting coefficients) of the components. The innovation performance of countries should be determined not only as an index, but also by including innovation effectiveness, efficiency and productivity performances of countries. Because by determining the innovation effectiveness, efficiency and productivity of the countries, the innovation performances of the countries can be evaluated multidimensionally and specific solutions for innovation problems can be created. In addition, by determining the multidimensional innovation effectiveness, efficiency and productivity of the countries, it will be possible to provide better management methods, strategies, practices and management of countries for innovation in the future. In addition, the number of innovation input and output components can be increased or different components specific to each country can be created to achieve more realistic results about countries innovation performances.

Keywords: Innovation, Global Innovation Index, Effectiveness, Efficiency, Productivity.

Öz: İnovasyon kavramı sadece işletmeler ve diğer örgütler için değil, ülkeler için de büyük önem taşımaktadır. Çünkü inovasyon kavramı bilim, sanat, teknoloji, sağlık ve sosyal boyutlar ile çoklu ağ yapısına sahip olduğu için inovasyon ülkelerin her alanda gelişmesini ve duruma göre değişimlerini sağlayabilmektedir. Ülkelerin inovasyon performansları sadece ülkelerin sahip oldukları küresel inovasyon endeks değerleri ile değil, ülkelerin inovasyon etkililik, etkinlik ve verimlilik performanslarıyla da değerlendirilmesi gerekmektedir. Çünkü inovasyon girdileri ve çıktıları arasındaki ilişkilerde maliyet analizi çerçevesinde optimal inovasyon performansı sağlamak önemlidir. Bu kapsamda araştırmanın birinci amacı, Avrupa Birliği ülkelerine göre küresel inovasyon girdi ve çıtı alt dizinlerini oluşturan bileşenlerin önemlilik derecelerini (ağırlık katsayıları) tespit etmektir. Araştırmanın diğer amaçları ise Avrupa Birliği ülkelerinin inovasyon etkililik, etkinlik ve verimlilik performans değerlerini tespit etmektir. Bulgulara istinaden ülkelere

www.turkishstudies.net/social 
göre en önemli inovasyon bileşeninin yaratıcı çıktısı olduğu tespit edilmiştir. Yine bulgulara göre inovasyon etkililiği en fazla olan üç ülke İsveç, Hollanda ve İngiltere, inovasyon etkinliği en fazla olan üç ülke Slovakya, Macaristan ve Lüksemburg ve inovasyon verimliliği en fazla olan üç ülke ise Yunanistan, Avusturya ve Portekiz olduğu tespit edilmiştir. Araştırmada çoğu ülkenin inovasyon etkililik, etkinlik ve verimlilik performans değerlerinin sıralamaları birbiriyle tutarlı olmadığı tespit edilmiştir. Dolayısıyla bu durum, inovasyon etkililiği, etkinliği ve verimliliği kavramlarının birbirlerinden farklı olduğunu göstermektedir.

Anahtar Kelimeler: İnovasyon, Küresel İnovasyon Endeksi, Etkililik, Etkinlik, Verimlilik.

\section{Giriş}

İnovasyon faaliyetleri, bir organizasyonun çevre içinde kurumsallaşmasını, meşruiyet kazanmasını, durumsallık yaklaşımı çerçevesinde çevre içinde koşullara göre uygun hareket etmesini, ilişkide bulunduğu çevre veya çevreler ile uyumlu olmasını ve çevre içinde yaşamasını sağlamaktadır. Bunun yanında inovasyon boyutundan hemen hemen tüm disiplinlerin istifade etmesinden, inovasyon boyutu ile fen, teknik ve beşeri alanlar arasında çok yönlü sarmal ilişkilerin olmasından ve inovasyon boyutunun teknoloji değişme ivmesi hızlı olan dünyaya uyumu veya entegrasyonu sağlamayı kolaylaştırmasından dolayı inovasyon temel bir faaliyet olarak düşünülebilmektedir.

Büyük organizasyonlar olarak nitelendirilen ülkeler inovasyon boyutuna her zaman ihtiyaç duydukları için inovasyon potansiyellerini, yeteneklerini, üstünlüklerini ve eksikliklerini çok iyi bilmesi gerekmektedir. Buna bağlı olarak ülkeler, kendilerinde inovasyon konusundaki yeterlilikleri hakkında farkındalık oluştuğunda, inovasyon konusunda mevcut bilgilerini sürekli olarak değerlendirme, mevcut inovasyon yeterliliklerini geliştirme ve inovasyon konusunda eksik hususlarını giderme fırsatını sağlayabilmektedirler. Bunun yanında ülkeler, kendi performansları hakkında bilgi sahibi olmasıyla sonraki inovasyon faaliyetlerin yöntemlerini, stratejilerini, uygulamalarını, planlamalarını ve inovasyon süreçlerinin yönetimini etkin, etkili ve verimli yapabilmektedirler.

Ülkelerin diğer ülkelerin inovasyon performansları hakkında bilgi sahibi olmaları, ülkelerin inovasyon konularını daha iyi öğrenmelerine neden olmaktadır. Çünkü ülkeler geliştirmek istediği veya eksik kaldığı inovasyon konularında inovasyon performansı iyi olan ülkeler ile işbirliği ve ortaklık sağlayabilmektedirler. Bu kapsamda ülkelerin kendilerinin inovasyon performanslarına önem vermesi kapsamında ülkelerin birbirleri ile inovasyon konularında işbirliği sağlamaları, ülkelerin inovasyon konularında birbirlerini tamamladığını göstermektedir. Böylece ülkeler, inovasyon performanslarını artırabilmekte ve küresel ekonomiye, küresel ticarete ve inovasyon faaliyetlerin geleceğine katkı sağlayabilmektedirler. Ayrıca ülkelerin diğer ülkelerin inovasyon performanslarını takip etmesi, ülkelerin kendileri için ekonomik ve ticari konularda fayda sağlamalarına neden olabilmektedir. Çünkü ülkeler birbirlerinin inovasyon anlamda kolaylıklarını, imkanlarını ve yeteneklerini tespit ederek yatırım kapasitesini artırabilmekte ve maliyetlerini azaltabilmektedirler. Dolayısıyla ülkeler, kendi inovasyon performanslarını belirleyecek uluslararası ölçütlere ve endekslere gereksinim duymaktadırlar.

Ülkelerin küresel anlamda inovasyon performanslarını ölçen bazı endeksler ve ölçütler bulunmaktadır. Söz konusu endekslerden bir tanesi küresel inovasyon endeksi olarak belirtilmiştir. Küresel inovasyon endeksi, 2019 yılı için Cornell Üniversitesi, INSEAD ve Birleşmiş Milletler kurumunda alanında uzmanlaşmış bir kurum olan WIPO tarafindan oluşturulmuştur. Küresel inovasyon endeksi, son y1llarda yenilik konusunda öncü bir referans olarak belirlenmiştir. İnovasyon kavramının ötesindeki insani yönleri daha detaylı olarak anlamak ve zengin inovasyon eğilimli ortamları yerel anlamda geliştirmeye yardımcı olan politikaların oluşturulması için küresel inovasyon endeks değerleri bu kapsamda büyük önem arz etmektedir. Çünkü inovasyon, ülkelerin

Turkish Studies - Social, 15(5) 
ekonomik olarak büyümelerinde ve refahlarının sağlanmasında bir itici kuvvet rolündedir. $\mathrm{Bu}$ kapsamda küresel inovasyon endeksi, AR-GE gibi geleneksel inovasyon önlemlerinin çok daha ötesine geçen göstergeleri içermektedir (Cornell Üniversitesi vd., 2019).

Ülkelerin inovasyon etkililik performansları, ülkelerin inovasyon çıktı alt dizin değerlerinin inovasyon girdi altdizin değerlerine oranlanması ile tespit edilebilmektedir. Ayrıca girdi ve çıktı ilişkileri anlamında ülkelerin inovasyon etkinlik performansları veri zarflama analizi, OCRA gibi çok kriterli karar verme teknikleri, ülkelerin inovasyon verimlilik performansları ise EATWIOS çok kriterli karar verme tekniği ile ölçülebilmektedir. Bu kapsamda bu çalışmada, 2019 y1lı için Avrupa Birliğine üye 28 ülkenin küresel inovasyon endeks ve bu endeksin girdi ve çıktı alt dizinlerine bağlı bileșen değerleri ile ülkelere göre inovasyon girdi ve çıktı alt dizin bileșenlerinin önemlilik dereceleri hesaplanmıştır. Devamında ise ülkelerin inovasyon etkililik, etkinlik ile verimlilik performansları çok kriterli karar verme teknikleri ile tespit edilerek tespit edilen değerler ülkeler bazında sıralanmıştır. Böylelikle çalışmada ülkelerin inovasyon etkililik, etkinlik ve verimlilik performans sıraları arasındaki tutarlılıklar ve farklılıklar saptanarak değerlendirmeler yapılmıştır.

\section{Kavramsal Çerçeve}

İnovasyon kelimesi latince "innavatus" kelimesinden türetilmiştir. Söz konusu “innavatus" kelimesi ise toplumsal, kültürel ve yönetsel bir ortamda yeni metotların uygulanması anlamına gelmektedir (Kılıç, 2018: 3). İnavatus kelimesinin kökeni "fare nuova" (yenilik yapmak), "innovare" (yenilemek) ve "novus" (yeni) kelimeleri ile ilişkilidir. Bu kapsamda inovasyon kelimesi yenilerini olușturmak için mevcut yapıların sırasını değiștirmek anlamına gelmektedir (Giunchiglia, 2013: 12). Türk Dil Kurumu'na göre ise inovasyon kavram1, yenilik veya yenileşim olarak tanımlanmaktadır (www.katalog.tdk.gov.tr, 2020).

Oslo klavuzunda ise yenilik, "İşletme içi uygulamalarda, işyeri organizasyonunda veya dı̧̧ ilişkilerde yeni veya önemli derecede iyileştirilmiş bir ürün (mal veya hizmet), veya süreç, yeni bir pazarlama yöntemi ya da yeni bir organizasyonel yönetimin gerçekleştirilmesidir." (OCED ve Eurostat, 2005: 50). Bu kapsamda yeniliğin olması için değişimin veya değişim faaliyetinin olması gerekmektedir. Dolayısıyla yenilik faaliyeti ise yeniliklerin uygulanmasını sağlayan ticari, finansal, teknolojik ve bilimsel girişimlerdir. Yenilik faaliyetlerinin bir kısmı yenilik özelliklerine sahiptir. Söz konusu yenilik faaliyetlerin diğer kısmı ise yenilik faaliyetlerini harekete geçiren faktör konumundadır. Ayrıca yenilik faaliyetleri özel yeniliklerin oluşması ile dolaylı olarak ilişkisi bulunan AR-GE faaliyetlerini de kapsamaktadır (OCED ve Eurostat, 2005: 51). Ayrıca literatürde yer alan inovasyon araştırmaları değerlendirildiğinde, inovasyon kavramı sık olarak AR-GE ve patent ile açıklandığı tespit edilmiştir (Süt ve Çetin, 2018: 299).

İnovasyon kavramı tanımından anlaşılacağı gibi bir nedensel analizde sonuç niteliğine sahiptir. Bu kapsamda sonuca ulaşmadaki süreçte yeniliğe ihtiyaç duyulmaktadır. Dolayısıyla inovasyon kavramı, hem sonuç hem de süreç özelliği taşımaktadır (TÜSİAD 2003, akt. Özbek ve Atik, 2013: 195, Kofler, vd., 2018: 9). İnovasyon boyutunun süreç kısmını etken ve edilgen olarak yenileme ve yenilenme faaliyetleri, inovasyon boyutunun sonuç kısmını ise yenileme ve yenilenme faaliyetleri sonucunda oluşan olumlu fayda ve getiri oluşturmaktadır (Mytelko ve Farinelli, 2000).

İnovasyon kavramı ilk olarak Schumpeter tarafindan "kalkınmanın itici gücü" olarak tanımlanmıştır. İnovasyon boyutu ülkelerin ekonomik olarak büyümesini ve gelişmesini sağlayan bir faktör özelliğini taşımaktadır (Cantwell, 2003; Clark ve Guy, 2010). Dolayısıyla ülkeler inovasyonun oluşturduğu farklılaşma ve çeşitlenme ile pazarda veya piyasada rekabet üstünlüğü sağlayabilmektedirler (Porter ve van der Linde, 1995; Wagner, 2009).

İnovasyon çeşitleri temel olarak, ürün ve hizmet yeniliği, süreç yeniliği, pazarlama yeniliği ve örgütsel yenilik olmak üzere 4 boyutta tasniflenmişlerdir. Söz konusu inovasyon çeşitleri ve onların açıklamaları aşağıda sunulmuştur (OCED ve Eurostat, 2005: 53-55). 
1. Ürün ve Hizmet Yeniliği: Bir ürünün ya da hizmetin mevcut durumundan daha iyileşmiş halini belirtmektedir. Bu durum, ürünün veya hizmetin teknik özelliklerinde iyileşme ve ürünü veya hizmeti oluşturan bileşenlerin hizmeti alan veya ürünü kullanan için ürünün veya hizmetin ideal işlevsel özellikleri sayesinde kolaylıkların sağlanmasını belirtmektedir.

2. Süreç Yeniliği: Mevcut duruma göre daha çok iyileştirilmiş, tercih edilebilecek ve ihtiyacı karşılayabilecek olan üretim ve teslimat metotlarının oluşturulmasıdır. Bu yenilikler, ürün ve hizmet için uygulanan tekniklerin ve malzeme yazılımlarının yenilenmesini kapsamaktadır.

3. Pazarlama Yeniliği: Ürünün dizaynındaki, ambalajındaki, konumlandırılmasındaki, tanımındaki ve ücretlendirilmesindeki yeniliği kapsamaktadır.

4. Örgütsel Yenilik: Organizasyonun ticari faaliyetlerinde ve organizasyonun çevresindeki ilişkilerde yeni örgütsel metotların uygulanmasıdır.

Yukarıda belirtilen 4 inovasyon çeşidi, ürünlerin ve hizmetlerin sürekli olarak yenilenmesini ve geliştirilmesini olanak sağlamaktadır. Bu kapsamda söz konusu inovasyon çeşitlerinin ideal olarak uygulanmasıyla organizasyonlar ve buna bağlı olarak ülkeler uzun vadede ekonomik anlamda fayda sağlayabilmektedirler (Burmaoğlu, 2012: 193).

İş yaşamında meydana gelen gelişmeler ve değişmeler farklı inovasyon çeşitlerinin oluşmasına neden olmuştur. Buna göre diğer farklı inovasyon çeşitleri ve onların açıklamaları aşağıda sunulmuştur (Soylu vd., 2019: 232).

1. Yönetim Inovasyonu: Klasik organizasyonel yapılarının yönetim faaliyetlerinin uygulanış şekillerinde koşullara göre önemli derecede değişiklik yapılarak organizasyonel hedefleri ilerleten ve organizasyonel hedeflerden fayda sağlanan yenilik faaliyetleridir.

2. Stratejik Inovasyon: Sektörlerdeki mevcut ürün, pazarlama ve rekabet yapılarını değiştiren ve buna bağlı olarak yeni bir pazar veya piyasa oluşturan inovasyon faaliyetleridir.

3. Açık Inovasyon: Organizasyonlara fayda sağlayacak her türlü inovasyon düşüncelerinin dikkate alınarak değerlendirilmesidir.

4. $\dot{I}_{S ̧}$ Modeli İnovasyonu: Organizasyonların kendi değerlerini oluşturmasındaki metotlarını, uygulamalarını, stratejilerini ve yönetimlerini belirtmektedir. İş modeli inovasyonu, organizasyonların temel değer zinciri üzerinde oluşturacağı yenilikleri, farklılaşmayı ve çeşitlenmeyi açıklamaktadır.

5. Alt Pazar İnovasyonu: Oluşturulan pazarda talep ve arz arasındaki uyumsuzluğu (talep azlığı) ortadan kaldırmak için pazar niteliğinin talebi oluşturacak bir yapıya getirme faaliyetleridir.

6. Ters Inovasyon: Gelişmekte olan ülkelerin, en az gelişmiş ülkelerde üretilen mal ve hizmet kalitesi kadar mal ve hizmet üreterek gelişmiş ülkelerin pazarında faaliyet göstermesidir.

İnovasyon organizasyon bazında sadece işletmeler için değil, ülkeler için de büyük öneme sahiptir. Çünkü ülkeler için inovasyon ekonomik büyümeyi ve gelişmeyi etkilemektedir. Bu kapsamda inovasyon ülkede yaşam beklentilerini artırır, teknolojinin herkes tarafindan erişebilme seviyesini yükseltir, yeni örgütsel oluşumları sağlar ve yaşam standardının artmasına yardımcı olur. Ayrıca inovasyon ülkelerin ekonomik yapılarını iyileştirir, küresel ekonomi ile uyum içinde olmasını ve rekabet etkinliğini, etkililiğini ve verimliliğini sağlar (Şahinli ve Kılıç, 2013: 340).

İnovasyon ile ilgili olarak ülkelerin inovasyon performanslarının ölçülmesinde yeni teknikler ve yöntemler üzerinde çalışılmaktadır. Ülkelerin inovasyon ölçüm çalışmaları öncelikli olarak Avrupa Komisyonu ve OECD tarafından gerçekleştirilmektedir. Ayrıca söz konusu çalışmalar Dünya Bankası, The Economist Intelligence Unit, INSEAD, Fraunhafer Enstitüsü gibi kurumlar tarafindan yapılmaktadır (Karaata, 2012, akt. Hancioğlu, 2012: 132). Bu kapsamda Küresel İnovasyon Endeksi, Küresel Rekabetçilik Endeksi, Avrupa İnovasyon Karnesi, En 
Yenilikçi Ekonomi Sıralaması ve Dünya Bankası Bilgi Ekonomisi Endeksi küresel anlamda kabul edilen ülkelerin inovasyon performanslarını ölçen endekslerdir (Yıldız, 2018: 108).

Küresel inovasyon endeksi, önceden belirlenen kriterler kapsamında ülkelerin inovasyon performanslarını analiz eden ve ülkelerin inovasyon performanslarına göre nicelik olarak büyükten küçüğe doğru sıralama yapan bir uygulamadır. Küresel inovasyon endeksi projesi, 2007 yılında INSEAD isimli Fransa' da bulunan bir yükseköğrenim kurumu tarafından oluşturulmuştur. Küresel inovasyon endeksinin oluşturulmasındaki amaç, inovasyonun zengin özelliklerinin kavranmasını sağlamaktır. Bunun yanında küresel inovasyon endeksi ile doktoralı çalışan işgücü sayısı ve oranı, araştırma merkezleri sayıs1, patent sayıs1, AR-GE maliyetleri gibi geleneksel kriterler haricinde nicelikler ölçülmeye çalışılmıştır (Şimşit vd., 2014: 3; Karaata, 2012: 11).

Küresel inovasyon endeksi, sadece ülkelerin inovasyon kapasitelerini ölçmek amaciyla değil, aynı zamanda ülkelerin inovasyon ile ilgili stratejilerini ve faaliyetlerini dikkate alarak söz konusu ülkelerin inovasyon konularındaki güçlü ve zayıf durumlarını tespit etmeye yönelik oluşturulmuştur (INSEAD, 2007). Küresel inovasyon endeksi, inovasyonu ölçmedeki uygulamaları geliştirmeye ve inovasyonun kapsamlı bir şekilde anlaşılmasına yöneltmektedir. Bunun yanında küresel inovasyon endeksi, kaliteli faaliyetler ile amaçlanan stratejilerin ve politikaların tanımlanmasını sağlamaktadır. Ayrıca küresel inovasyon endeksi, inovasyonu oluşturan bileşenlerin sürekli olarak değerlendirmekte ve buna bağlı olarak söz konusu bileşenlerin güncel yapıya sahip olması için bilgiler sağlamaktadır. Dolayısıyla bu endeks, her yıl birçok ekonomiyi kapsayan metrik bir uygulamayı açıklamaktadır (Savaşc1, 2017: 1; Benavente vd., 2012: 4).

Küresel inovasyon endeksinin inovasyon girdi ve çıtı alt dizinleri bulunmaktadır. İnovasyon girdi alt dizini kurumlar, beşeri sermaye ve araştırma, altyapı, pazar gelişmişliği ve iş gelişmişliği bileşenlerinden oluşmaktadır. İnovasyon çıktı alt dizini ise bilgi ve teknoloji ile yaratıcı çıtı bileşenlerinden oluşmaktadır. Bunun yanında inovasyon girdi ve çıtı alt dizinlerine bağlı bileşenlerin yanında, bileșenlere bağlı değişkenler ve değişkenlere bağlı alt değişkenlerde bulunmaktadır (Cornell University vd., 2019).

Küresel inovasyon endeksi verileri kamu ve özel sektör kurumlarından, uzman kuruluşların yayınladıkları endekslerden ve Dünya Ekonomik Formu Yönetici anketi ile elde edilen verilerden oluşmaktadır (Ay Türkmen ve Aynaoğlu, 2017: 261). 
Şekil 1: Küresel İnovasyon Endeksi Alt Dizinleri, Bileşenleri ve Değişkenleri

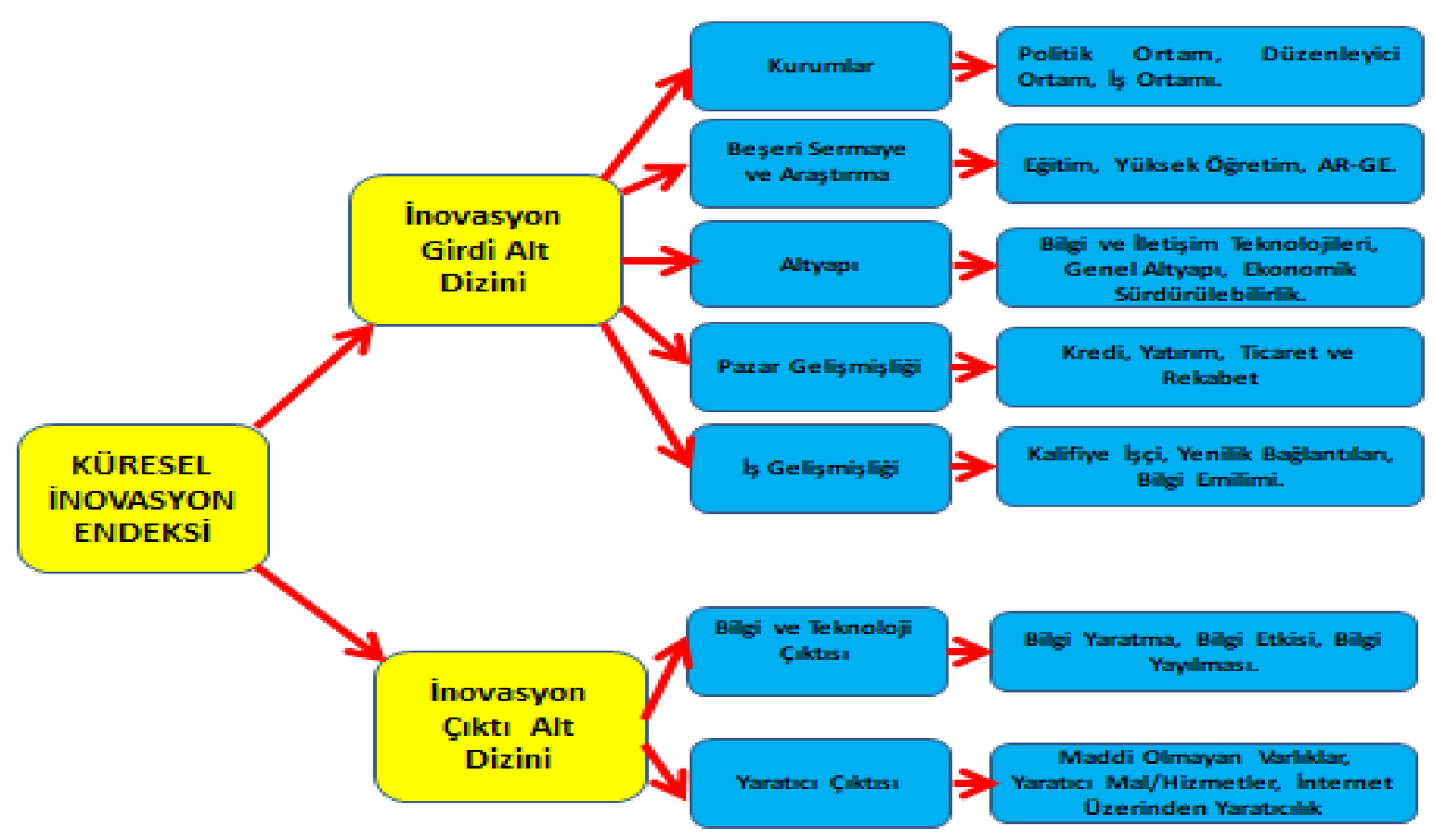

Kaynak: Ay Türkmen ve Aynaoğlu, 2017: 262

Şekil 1'de belirtilen inovasyon dizinleri, bileşen ve değişken değerleri, sadece ülkelerin makro anlamda genel yenilik kapasiteleri ile ilgili olarak bilgi vermektedir. Bu sebeple herhangi bir hizmet sektörünün inovasyon performansı, küresel inovasyon endeksi ile ölçülememektedir. Dolayısıyla hizmet sektörlerinin inovasyon performansları insan kaynakları, inovasyon talebi, teknolojik birikim, teknolojik olmayan değişimler, bilginin kaynağı ve yayılması, ticarileştirme ve fikri mülkiyet göstergeleri ile tespit edilebilmektedir (Gaberli, 2019: 126).

Küresel inovasyon endeksi, inovasyon girdi ve inovasyon çıtı alt dizin değerlerinin aritmetik ortalaması ile hesaplanmaktadır (Cornell University vd., 2019). Ayrıca küresel inovasyon endeksi kapsamında ülkelerin inovasyon etkililik performans değerleri de hesaplanabilmektedir. Ülkelerin inovasyon etkililik performans değerleri, inovasyon çıtı alt dizin değerlerinin, inovasyon girdi alt dizin değerlerine oranlaması ile hesaplanmaktadır. Bu oran 1 adet girdiden ne kadar çok çıktı oluştuğunu göstermektedir (Hancıoğlu, 2016: 136).

Ülkelerin inovasyon performansları, inovasyon girdileri ve çıktıları arasındaki ilişkiler kapsamında daha kapsamlı olarak hesaplanabilir. Dolayısıyla söz konusu ülkelerin inovasyon performansları sadece ülkelerin sahip olduğu endeks ile değil, aynı zamanda inovasyon etkililik, etkinlik ve verimlilik performansları açısından da değerlendirilebilir. Böylelikle bir ülkenin inovasyon konusunda amaçlarının doğru belirlenme düzeyi (etkinlik), inovasyon faaliyetlerinin doğruluğu (etkililik) veya inovasyon amaçlarına ulaşma düzeyi (etkililik) ve doğru inovasyon faaliyetlerinin yapılması (verimlilik) düzeyi tespit edilebilir. Buna bağlı olarak ülkelerin inovasyon konusundaki sorunların spesifik olarak analizi yapılabilir. Söz konusu spesifik analiz çerçevesinde inovasyon girdileri ve çıktıları arası ilişkilerde inovasyon problemlerin çözümüne veya inovasyonun ilerlemesine yönelik hangi girdilerin veya çıtılıarın iyileştirilmesi gerektiğinin tespiti derin analizler ile sağlanabilecektir. Sonuç olarak ülkelerin inovasyon etkililiğinin, etkinliğinin ve verimliliğinin ölçülmesi ile ülkelerin inovasyon performansları çok boyutlu olarak değerlendirilebilecektir. 


\section{Literatür}

Küresel inovasyon endeksi ile ilgili olarak ulusal ve uluslararası literatürde araştırmalar bulunmaktadır. $\mathrm{Bu}$ anlamda literatürde tespit edilen küresel inovasyon endeksi ile ilgili olan araştırmaların açıklamaları aşağıda sunulmuştur.

- Kijek ve Kijek (2010), "The Analysis of Innovation Input-Output Relationships in EU Member States" isimli araştırmasında 2005 ve 2006 yılları için 22 Avrupa Birliği ülkesinin küresel inovasyon endeksini belirleyen bileşenlere ait değerler kapsamında inovasyon girdileri ve çıktıları arasındaki ilişkileri incelemişlerdir. Bulgulara göre, inovasyon girdi ve çıktı kümeleri arasında bütünsel anlamda anlaml, pozitif yönlü ve çok yüksek düzeyde ilişki olduğu tespit edilmiştir. Ayrıca araştırmada AR-GE harcamalarının, bilgi ve iletişim teknolojilerinin ve beşeri sermayenin inovasyon çıktısını belirleyen temel inovasyon girişimleri olduğu tespit edilmiştir.

- Layos ve Peña (2020), “Can Innovation Save Us? Understanding the Role of Innovation in Mitigating the Covid-19 Pandemic in ASEAN-5 Economies"' isimli araştırmasında ASEAN-5 grubu ülkelerinin (Malezya, Endonezya, Filipinler, Singapur, Tayland) küresel inovasyon endeksini oluşturan bileşenlerin değerleri ve COVID 19 salgın hastalığına karşı yapılan faaliyetlerin dereceleri doğrultusunda ülkelerin inovasyon sistemleri ile söz konusu salgın hastalığa karşı tepki düzeyi arasındaki ilişkileri incelemişlerdir. Araştırma sonucuna göre, inovasyon sistemleri ile ülkelerin salgın hastalığa karşı olan tepkileri arasında pozitif yönlü ve anlamlı ilişkilerin olduğu tespit edilmiştir.

- Jintana vd. (2020), "Innovation Ecosystem of ASEAN Countries" isimli araştırmasında ASEAN grubunda yer alan 10 ülkenin küresel inovasyon endeksini oluşturan bileşenlere ait değerler üzerinden söz konusu ülkelerin inovasyon ekosistemlerini araştırmışlardır. Bulgulara göre, Singapur ülkesinin tüm inovasyon sistemlerinin (tüm inovasyon bileşenlerinin), Vietnam ülkesinin inovasyon altyapısının ve Kamboçya ülkesinin pazar gelişmişliği inovasyonunun iyi derecede oldukları tespit edilmiştir. Buna karşın Endonezya'nın kurum inovasyonu, Filipinler, Tayland ve Malezya ülkelerinin iş gelişmişliği inovasyonu konusunda kendilerini geliştirmeleri gerektiği sonucuna varılmıştır.

- Sohn ve Kim (2016), “Re-evaluation of Global Innovation Index Based on A Structural Equation Model" isimli araştırmasında 2013 y1lı küresel inovasyon raporu kapsamında tüm ülkelerin küresel inovasyon endeksini oluşturan bileşenlerin değerleri üzerinden inovasyon girdileri ve çıktıları arasındaki ilişkileri incelemişlerdir. Araştırma sonucuna göre, inovasyon girdileri ve çıktıları arasında ilişkilerin tümünün anlamlı, pozitif yönlü ve genel anlamda orta düzeyde olduğu tespit edilmiştir. Araştırmada özellikle iş gelişmişliği ve altyapı inovasyon girdi bileşenlerinin yaratıcı çıktısını anlamlı, pozitif yönlü ve yüksek seviyede etkilediği tespit edilmiştir.

- Khedhaouria ve Roy (2017), "Configurational Conditions of National Innovation Capability: A fuzzy Set Analysis Approach" isimli araştırmasında 2012 ve 2015 yılları arasındaki 133 ülkenin küresel inovasyon endeksini belirleyen inovasyon bileşenlerine ait değerler üzerinden inovasyon kapasitesini belirleyen bileşenleri tespit etmişlerdir. Araştırma sonucuna göre, beşeri sermaye ve araştırma, altyapı, pazar gelişmişliği girdilerinin ülkelerin genel anlamda inovasyon kapasitelerini veya çıktılarını yüksek derecede artıran bileşenler olduğu tespit edilmiştir.

- Hancıoğlu (2016), “Küresel İnovasyon Endeksini Oluşturan İnovasyon Girdi ve Çıktı Göstergeleri Arasındaki İlişkinin Kanonik Korelasyon Analizi ile İncelenmesi: OECD Örneği” isimli araştırmasında OECD ülkelerinin 2011-2015 y1lına ait küresel inovasyon endeksini oluşturan inovasyon girdi ve çıktı alt dizinlerine ait bileşen değerleri üzerinden inovasyon girdileri ve çıktıları arasındaki ilişkiyi bütünsel anlamda tespit etmiştir. Araştırma sonucuna göre, inovasyon girdi ve çıtı bileşen kümeleri arasında bütünsel anlamda anlamlı, pozitif yönlü ve yüksek düzeyde ilişki olduğu tespit edilmiştir. 
- Ay Türkmen ve Aynaoğlu (2017), “Küresel Rekabet Endeksi Göstergelerinin Küresel İnovasyon Endeksi Üzerindeki Etkisi”" isimli araştırmasında 2009 ve 2017 yılları arasındaki 2009 y1lında ilk 30'daki 29 ülkenin küresel inovasyon endeksini ve küresel rekabet endeksini oluşturan bileşenlere ait değerler üzerinden küresel rekabet endeksi parametrelerin küresel inovasyon endeksi parametresi üzerindeki etkiyi araştırmışlardır. Araştırma sonucuna göre, küresel rekabet endeksi bileşenlerinden olan makroekonomik çevrenin küresel inovasyon endeksini en düşük seviyede etkileyen küresel rekabet bileşeni olduğu tespit edilmiştir. Ayrıca araştırmada küresel rekabet endeksini oluşturan faktörlerden sadece inovasyon ve uzmanlaşma faktörünün küresel inovasyon endeksini pozitif yönlü ve anlamlı etkilediği tespit edilmiştir.

- Jankowska vd. (2017), “Efficiency of National Innovation Systems-Poland and Bulgaria in The Context of the Global Innovation Index" isimli araştırmasında 2015 yılı için Bulgaristan ve Polonya ülkelerinin küresel inovasyon endeksi değerleri üzerinden söz konusu ülkelerin inovasyon performanslarını karşılaştırmışlardır. Bulgulara göre, Polonya ülkesinin inovasyon faaliyetlerin fazla olduğunu, buna rağmen Polonya'nın yüksek inovasyon çıktısına sahip olan ülkeler arasında yer almadığ 1 tespit edilmiştir. Bunun yanında Bulgaristan ülkesinin ise inovasyon girdileri için kendisini geliştirmesi gerektiği, buna karşın inovasyon çıktılarının yeterli seviyede olduğu sonucuna ulaş1mıştır.

\section{Metodoloji}

\section{Araştırmanın Veri Seti, Amacı ve Analiz düzeyi}

Araştırmanın veri setini Avrupa Birliği’ne üye 28 ülkenin küresel inovasyon endeksini (performansını) belirleyen ve söz konusu endeksin girdi ve çıktı alt dizinlerini oluşturan bileşenlerin verileri oluşturmuştur. Araştırma için veriler www.globalinnovationindex.org internet adresinden temin edilmiştir. Araştırma kapsamında verilerin elde edilmesinde Microsoft Office 2010 Excel programından faydalanılmıştır. Araştırmada veri setini oluşturan 5 inovasyon girdi ve 2 inovasyon çıtı bileşenleri (veri seti) ve araştırmaya kolaylık sağlaması açısından bileşenlerin kısaltılmış kodları Tablo 1'de belirtilmiştir.

Tablo 1: Araştırmanın Veri Seti ve Veri Setinde Bulunan Bileşenlerin Kısaltmaları

\begin{tabular}{|c|c|c|c|}
\hline İnovasyon Girdi Alt Endeksleri & Kisaltması & İnovasyon Çıktı Alt Endeksleri & Kisaltması \\
\hline Kurumlar & G1 & & \\
\hline Beşeri Sermaye ve Araştırma & G2 & Bilgi ve Teknoloji Çıktısı & Ç1 \\
\hline Altyap 1 & G3 & & \\
\hline $\begin{array}{l}\text { Pazar Gelişmişliği } \\
\text { İș Gelişmişliği }\end{array}$ & $\begin{array}{l}\text { G4 } \\
\text { G5 }\end{array}$ & Yaratıcı Çıktısı & Ç2 \\
\hline
\end{tabular}

Araştırmanın 4 amacı bulunmaktadır. Söz konusu bu amaçlar aşağıda maddeler halinde sunulmuştur.

1. Entropi yöntemi ile inovasyon girdi ve çıktı alt dizinlerine bağlı bileşenlerin ülkelere göre önemlilik derecelerini (ağırlık katsayılarını) tespit etmek ve onları sıralamak.

2. Ülkelerin inovasyon etkililik performans değerlerini tespit etmek ve onları sıralamak.

3. OCRA (Operational Competitiveness Rating) yöntemi ile ülkelerin inovasyon etkinlik performanslarını belirleyerek onları sıralamak.

4. EATWIOS (Efficiency Analysis Technique with Input and Output Satisfaction) yöntemi ile ülkelerin inovasyon verimlilik performanslarını hesaplayarak onları sıralamak.

Avrupa Birliği ülkeleri dünya nüfusunun yalnızca \%7'sini oluşturmasına rağmen dünya GSYH'sının yaklaşık olarak \%26'sını oluşturmaktadır (www.izto.org.tr, 2020). Dolayısıyla Avrupa 
Birliği ülkelerinde inovasyon konularındaki stratejilerinde, yöntemlerinde, yönetimlerinde, tekniklerinde ve uygulamalarında meydana gelen en küçük değişiklik dünya ekonomisini ve diğer ülkelerin inovasyon faaliyetlerini etkileyebilmektedir. Bu durum, dünya ekonomisinin ve diğer ülkelerin inovasyon faaliyetlerinin Avrupa Birliği ülkelerinin inovasyon faaliyetlerine göre türevinin fazla olduğu anlamına gelmektedir. Sonuç olarak Avrupa Birliği ülkelerinin inovasyon faaliyetleri bu açıdan önemli olduğu değerlendirilerek çalışmada inovasyon performansları araştırılan ülkeler Avrupa Birliği ülkeleri olmuştur.

\section{Araștırmanın Önemi ve Katkısı}

Ulusal ve uluslararası literatür tarandığında 2019 yılı için Avrupa Birliğine üye ülkelerin küresel inovasyon endeksleri kapsamında yukarıda belirtilen amaçların tespit edilmesine yönelik bir araştırmaya rastlanılmamıştır. Dolayısıyla bu araştırma, belirtilen özellikleri açıklayan literatürdeki ilk çalışmadır. Araştırma kapsamında anılan yöntemler dahilinde tespit edilen veriler araştırmacılara veri seti niteliği kazandırmıştır. Ayrıca bu araştırma, ülkelerin inovasyon performansları sadece endeks ile değil, inovasyon etkililik, etkinlik ve verimlilik performanslarının ölçümlerine yönelik bir yöntem niteliği de taşımaktadır.

\section{Bulgular}

Entropi Yöntemi ile Kriterlerin (İnovasyon Girdi ve Çıktı Alt Dizini Bileşenlerinin) Önemlilik Derecelerinin (Ă̆ırlık Katsayılarının) Tespiti

Entropi yönteminde ilk olarak karar matrisinin oluşturulması gerekmektedir. Söz konusu karar matrisi Tablo 2'de belirtilmiştir. 
Tablo 2: Küresel İnovasyon Girdi ve Çıktı Alt Dizini Bileşen Değerleri (Karar Matrisi)

\begin{tabular}{|c|c|c|c|c|c|c|c|}
\hline \multirow{2}{*}{ ÜLKELER } & \multicolumn{5}{|c|}{ GİRDİLER } & \multicolumn{2}{|c|}{ ÇIKTILAR } \\
\hline & G1 & $\mathrm{G} 2$ & G3 & G4 & G5 & Ç1 & Ç2 \\
\hline Almanya & 86,4 & 63,2 & 62 & 58,6 & 56,1 & 52,7 & 49,6 \\
\hline Avusturya & 86 & 60,2 & 61,4 & 52,8 & 53,8 & 36,7 & 41,4 \\
\hline Belçika & 82 & 55 & 57,2 & 55,3 & 54,1 & 40,8 & 38,5 \\
\hline Bulgaristan & 68,3 & 30,6 & 53,7 & 47,5 & 40,3 & 31,4 & 33,8 \\
\hline Çekya & 78,6 & 43,4 & 56,4 & 52,4 & 46,3 & 43,8 & 43,1 \\
\hline Danimarka & 91,7 & 63,1 & 65,8 & 66,9 & 59,1 & 46,4 & 48,6 \\
\hline Estonya & 81,7 & 42,1 & 61,5 & 52,6 & 42,6 & 36 & 51,7 \\
\hline Finlandiya & 93,6 & 63,4 & 62,1 & 57,3 & 63,9 & 55,1 & 48,1 \\
\hline Fransa & 83,2 & 55,8 & 62,3 & 62,9 & 53,3 & 45 & 45 \\
\hline GKRK & 80,3 & 35,8 & 55,9 & 58,2 & 47,6 & 41,2 & 41,1 \\
\hline Hirvatistan & 69,3 & 35,6 & 51,6 & 46 & 34,3 & 25,6 & 31 \\
\hline Hollanda & 90,9 & 52,4 & 61,8 & 58,2 & 63,7 & 61,8 & 53,2 \\
\hline İngiltere & 87,1 & 59,3 & 64,4 & 76 & 54,3 & 56,6 & 52,2 \\
\hline İlanda & 85,5 & 48,4 & 66,3 & 54,6 & 55,8 & 56,9 & 43,3 \\
\hline İspanya & 78,1 & 47 & 63,1 & 59,5 & 38,7 & 37,2 & 39,7 \\
\hline İsveç & 90,1 & 62,1 & 69,1 & 62,1 & 68,8 & 61,8 & 51,9 \\
\hline İtalya & 75,3 & 45,4 & 59,4 & 51,4 & 42,2 & 38,9 & 36,8 \\
\hline Letonya & 77,2 & 36,9 & 50,5 & 54,4 & 37,4 & 27,5 & 42,8 \\
\hline Litvanya & 76 & 36,3 & 51,7 & 50,9 & 38 & 24,4 & 40,3 \\
\hline Lüksemburg & 80,7 & 41,7 & 58,7 & 46,9 & 60,7 & 42,2 & 56,2 \\
\hline Macaristan & 71,6 & 41 & 52,7 & 45,7 & 40,8 & 42,8 & 34,6 \\
\hline Malta & 75,2 & 36,6 & 61,1 & 45,2 & 54,9 & 31,9 & 55 \\
\hline Polonya & 73,6 & 41,2 & 53,8 & 47,9 & 38,4 & 30,9 & 32,4 \\
\hline Portekiz & 81,8 & 47,7 & 56,8 & 49,8 & 37,3 & 29,8 & 39,4 \\
\hline Romanya & 67,1 & 29,1 & 54,5 & 43,2 & 33,6 & 30,3 & 25,8 \\
\hline Slovakya & 73,1 & 32,4 & 54,2 & 47,4 & 35,6 & 34 & 37,1 \\
\hline Slovenya & 82,3 & 46,6 & 53,9 & 43,6 & 44,1 & 30,7 & 42,1 \\
\hline Yunanistan & 67,2 & 49,5 & 51,7 & 50,3 & 32,4 & 25,1 & 30,1 \\
\hline Maksimum & 93,6 & 63,4 & 69,1 & 76 & 68,8 & 61,8 & 56,2 \\
\hline Minimumum & 67,1 & 29,1 & 50,5 & 43,2 & 32,4 & 24,4 & 25,8 \\
\hline
\end{tabular}

Araştırmada kriterlerin entropi katsayılarının tespit edilmesi için karar matrisindeki değerlerin normalize işlemi yapılmalıdır. Normalize işleminde karar matrisindeki değerler " 0 " ile " 1 " değeri arasında olmasını sağlayarak standart hale getirilir. Bu anlamda Tablo 2'de belirtilen karar matrisindeki değerlerin normalize değerleri Tablo 3 'te belirtilmiştir. 
Avrupa Birliği Ülkelerinin İnovasyon Etkililik, Etkinlik ve Verimlilik Performanslarının... 2349

\begin{tabular}{|c|c|c|c|c|c|c|c|}
\hline \multicolumn{8}{|c|}{ Tablo 3: Normalize Karar Matrisi } \\
\hline \multirow{2}{*}{ ÜLKELER } & \multicolumn{5}{|c|}{ GÍRDİLER } & \multicolumn{2}{|c|}{ ÇIKTILAR } \\
\hline & G1 & G2 & G3 & G4 & G5 & Ç1 & Ç2 \\
\hline Almanya & 0,038677 & 0,048548 & 0,037953 & 0,039129 & 0,042241 & 0,047159 & 0,041864 \\
\hline Avusturya & 0,038498 & 0,046244 & 0,037586 & 0,035256 & 0,040509 & 0,032841 & 0,034943 \\
\hline Belçika & 0,036707 & 0,042249 & 0,035015 & 0,036926 & 0,040735 & 0,03651 & 0,032495 \\
\hline Bulgaristan & 0,030574 & 0,023506 & 0,032872 & 0,031717 & 0,030344 & 0,028098 & 0,028528 \\
\hline Çekya & 0,035185 & 0,033338 & 0,034525 & 0,034989 & 0,034862 & 0,039195 & 0,036377 \\
\hline Danimarka & 0,041049 & 0,048471 & 0,040279 & 0,044671 & 0,0445 & 0,041521 & 0,04102 \\
\hline Estonya & 0,036573 & 0,03234 & 0,037647 & 0,035123 & 0,032076 & 0,032215 & 0,043636 \\
\hline Finlandiya & 0,0419 & 0,048702 & 0,038014 & 0,038261 & 0,048114 & 0,049306 & 0,040598 \\
\hline Fransa & 0,037244 & 0,042864 & 0,038137 & 0,042001 & 0,040133 & 0,040268 & 0,037981 \\
\hline GKRK & 0,035946 & 0,0275 & 0,034219 & 0,038862 & 0,035841 & 0,036868 & 0,034689 \\
\hline Hurvatistan & 0,031022 & 0,027347 & 0,031587 & 0,030716 & 0,025826 & 0,022908 & 0,026165 \\
\hline Hollanda & 0,040691 & 0,040252 & 0,037831 & 0,038862 & 0,047963 & 0,055302 & 0,044902 \\
\hline İngiltere & 0,03899 & 0,045552 & 0,039422 & 0,050748 & 0,040885 & 0,050649 & 0,044058 \\
\hline İrlanda & 0,038274 & 0,037179 & 0,040585 & 0,036458 & 0,042015 & 0,050917 & 0,036546 \\
\hline İspanya & 0,034961 & 0,036104 & 0,038626 & 0,03973 & 0,029139 & 0,033289 & 0,033508 \\
\hline İsveç & 0,040333 & 0,047703 & 0,042299 & 0,041466 & 0,051803 & 0,055302 & 0,043805 \\
\hline İtalya & 0,033708 & 0,034875 & 0,036361 & 0,034322 & 0,031775 & 0,03481 & 0,03106 \\
\hline Letonya & 0,034558 & 0,028345 & 0,030913 & 0,036325 & 0,028161 & 0,024609 & 0,036124 \\
\hline Litvanya & 0,034021 & 0,027884 & 0,031648 & 0,033988 & 0,028612 & 0,021834 & 0,034014 \\
\hline Lüksemburg & 0,036125 & 0,032033 & 0,035933 & 0,031317 & 0,045704 & 0,037763 & 0,047434 \\
\hline Macaristan & 0,032052 & 0,031495 & 0,03226 & 0,030515 & 0,030721 & 0,0383 & 0,029203 \\
\hline Malta & 0,033663 & 0,028115 & 0,037402 & 0,030182 & 0,041337 & 0,028546 & 0,046421 \\
\hline Polonya & 0,032947 & 0,031648 & 0,032933 & 0,031985 & 0,028913 & 0,027651 & 0,027346 \\
\hline Portekiz & 0,036618 & 0,036642 & 0,03477 & 0,033253 & 0,028085 & 0,026667 & 0,033255 \\
\hline Romanya & 0,030037 & 0,022354 & 0,033362 & 0,028846 & 0,025299 & 0,027114 & 0,021776 \\
\hline Slovakya & 0,032723 & 0,024889 & 0,033178 & 0,031651 & 0,026805 & 0,030425 & 0,031313 \\
\hline Slovenya & 0,036841 & 0,035797 & 0,032995 & 0,029113 & 0,033205 & 0,027472 & 0,035533 \\
\hline Yunanistan & 0,030082 & 0,038024 & 0,031648 & 0,033587 & 0,024396 & 0,022461 & 0,025405 \\
\hline
\end{tabular}

Tablo 3'te belirtilen normalize karar matrisinde belirtilen değerler üzerinden her bir karar alternatifine karşılık gelen kriterlere ait değerler ile söz konusu değerlerin doğal logaritmanın çarpımı sonucunda yeni matris değerleri oluşturulur. Söz konusu oluşturulan yeni matris değerleri üzerinden kriterlere ait entropi değerleri (ej), entropi değerleri üzerinden kriterlere ait farklılaşma dereceleri (dj), farklılaşma dereceleri üzerinden ise kriterlerin entropi kriter ağırlıkları (wj) tespit edilebilmektedir. $\mathrm{Bu}$ anlamda Tablo 3 'te belirtilen normalize değerler üzerinden tespit edilen yeni matris değerleri, kriterlerin entropi değerleri (ej), farklılaşma dereceleri (dj) ve entropi kriter ağırlıkları (wj) Tablo 4'te gösterilmiştir. 
Tablo 4: Yeni Matris, Kriterlere Ait Entropi, Farklılaşma ve Entropi Kriter Ağırlık Değerleri YENİ MATRİS DEĞERLERİ

\begin{tabular}{|c|c|c|c|c|c|c|c|}
\hline \multirow{2}{*}{ ÜLKELER } & \multicolumn{5}{|c|}{ GİRDİLER } & \multicolumn{2}{|c|}{ ÇIKTILAR } \\
\hline & G1 & $\mathrm{G} 2$ & G3 & G4 & G5 & Ç1 & Ç2 \\
\hline Almanya & $-0,125797$ & $-0,146868$ & $-0,12416$ & $-0,126813$ & $-0,133665$ & $-0,144034$ & $-0,132847$ \\
\hline Avusturya & $-0,125393$ & $-0,142145$ & $-0,123324$ & $-0,117936$ & $-0,129881$ & $-0,112188$ & $-0,117199$ \\
\hline Belçika & $-0,121309$ & $-0,133684$ & $-0,117369$ & $-0,121812$ & $-0,130379$ & $-0,120854$ & $-0,111349$ \\
\hline Bulgaristan & $-0,106631$ & $-0,088159$ & $-0,112263$ & $-0,109453$ & $-0,106057$ & $-0,100369$ & $-0,10147$ \\
\hline Çekya & $-0,117769$ & $-0,113386$ & $-0,116214$ & $-0,117309$ & $-0,117009$ & $-0,12696$ & $-0,120548$ \\
\hline Danimarka & $-0,13107$ & $-0,146712$ & $-0,129373$ & $-0,138858$ & $-0,138495$ & $-0,132102$ & $-0,131004$ \\
\hline Estonya & $-0,120999$ & $-0,110973$ & $-0,123463$ & $-0,117623$ & $-0,11033$ & $-0,110668$ & $-0,136663$ \\
\hline Finlandiya & $-0,132926$ & $-0,147179$ & $-0,124299$ & $-0,124859$ & $-0,145986$ & $-0,148398$ & $-0,130077$ \\
\hline Fransa & $-0,122543$ & $-0,135009$ & $-0,124576$ & $-0,133145$ & $-0,129049$ & $-0,12935$ & $-0,124224$ \\
\hline GKRK & $-0,119547$ & $-0,098824$ & $-0,115488$ & $-0,126214$ & $-0,119302$ & $-0,12168$ & $-0,116602$ \\
\hline Hirvatistan & $-0,107741$ & $-0,098425$ & $-0,109133$ & $-0,106982$ & $-0,09443$ & $-0,086508$ & $-0,095327$ \\
\hline Hollanda & $-0,130283$ & $-0,129313$ & $-0,123881$ & $-0,126214$ & $-0,14568$ & $-0,160096$ & $-0,139343$ \\
\hline İngiltere & $-0,126501$ & $-0,140706$ & $-0,127469$ & $-0,151274$ & $-0,13071$ & $-0,151077$ & $-0,13756$ \\
\hline İrlanda & $-0,124887$ & $-0,122394$ & $-0,130049$ & $-0,120735$ & $-0,133176$ & $-0,151609$ & $-0,120938$ \\
\hline İspanya & $-0,117243$ & $-0,119914$ & $-0,125683$ & $-0,128156$ & $-0,103027$ & $-0,113266$ & $-0,113792$ \\
\hline İsveç & $-0,129493$ & $-0,145149$ & $-0,133792$ & $-0,131982$ & $-0,153353$ & $-0,160096$ & $-0,137022$ \\
\hline İtalya & $-0,11427$ & $-0,117039$ & $-0,120511$ & $-0,115732$ & $-0,109594$ & $-0,116886$ & $-0,107835$ \\
\hline Letonya & $-0,116293$ & $-0,101003$ & $-0,107472$ & $-0,120426$ & $-0,100528$ & $-0,091166$ & $-0,119961$ \\
\hline Litvanya & $-0,115018$ & $-0,099818$ & $-0,109283$ & $-0,114938$ & $-0,101686$ & $-0,083501$ & $-0,115001$ \\
\hline Lüksemburg & $-0,119963$ & $-0,110224$ & $-0,119517$ & $-0,108469$ & $-0,141024$ & $-0,123727$ & $-0,144599$ \\
\hline Macaristan & $-0,110271$ & $-0,108907$ & $-0,110779$ & $-0,106484$ & $-0,106994$ & $-0,124946$ & $-0,103189$ \\
\hline Malta & $-0,114163$ & $-0,100411$ & $-0,122904$ & $-0,105651$ & $-0,1317$ & $-0,101516$ & $-0,142513$ \\
\hline Polonya & $-0,112443$ & $-0,109284$ & $-0,112411$ & $-0,110107$ & $-0,102453$ & $-0,099214$ & $-0,098424$ \\
\hline Portekiz & $-0,121103$ & $-0,121158$ & $-0,116792$ & $-0,113181$ & $-0,100335$ & $-0,096649$ & $-0,113184$ \\
\hline Romanya & $-0,10529$ & $-0,084961$ & $-0,113442$ & $-0,102282$ & $-0,093025$ & $-0,09782$ & $-0,083335$ \\
\hline Slovakya & $-0,111902$ & $-0,091922$ & $-0,113001$ & $-0,10929$ & $-0,097012$ & $-0,106259$ & $-0,10846$ \\
\hline Slovenya & $-0,121618$ & $-0,119199$ & $-0,112558$ & $-0,102961$ & $-0,113066$ & $-0,098751$ & $-0,118585$ \\
\hline Yunanistan & $-0,105402$ & $-0,124322$ & $-0,109283$ & $-0,113982$ & $-0,09059$ & $-0,085261$ & $-0,093308$ \\
\hline \multirow{2}{*}{\multicolumn{8}{|c|}{0,300101629}} \\
\hline & & & & & & & \\
\hline ej & 0,218465 & 0,231364 & 0,216884 & 0,219729 & 0,226723 & 0,221027 & 0,214398 \\
\hline \multicolumn{8}{|c|}{ FARKLILAŞMA DERECELERİ } \\
\hline $\mathrm{dj}$ & 0,781535 & 0,768636 & 0,783116 & 0,780271 & 0,773277 & 0,778973 & 0,785602 \\
\hline \multicolumn{8}{|c|}{ KRİTER AĞIRLILIKLARI } \\
\hline wj & 0,143364 & 0,140998 & 0,143654 & 0,143132 & 0,141849 & 0,142894 & 0,14411 \\
\hline Siralama & 3 & 7 & 2 & 4 & 6 & 5 & 1 \\
\hline
\end{tabular}

Tablo 4'e göre, inovasyon girdi ve çıtıtı alt dizini bileşenlerinin önemlilik dereceleri (ağırlık katsayıları) arasında belirgin farklılıklar bulunmamaktadır. Bu kapsamda Tablo 4'e göre, ülkelere göre inovasyon girdi ve çıktı dizini bileşenlerinin önemlilik dereceleri (ağırlık katsayıları) Ç2 (Yaratıc1 Çıktısı=0,14411), G3 (Altyapı=0,143654), G1 (Kurumlar=0,143364), G4 (Pazar 
Gelişmişliği=0,143132), Ç1 (Bilgi ve Teknoloji Çıktısı=0,142894), G5 (İş Gelişmişliği $=0,141849$ ) ve G2 (Beşeri Sermaye ve Araştırma=0,140998) olarak sıralanmıştır. Ayrıca Tablo 4'e göre, Avrupa Birliği ülkelerinin çıktı inovasyon bileşenlerinin ortalama önemlilik derecesi, girdi inovasyon bileşenlerinin ortalama önemlilik derecesinden fazla olduğu tespit edilmiştir (Ç1, Ç2 Ortalama $=0,143502>$ G1, G2, G3, G4, G5 Ortalama=0,142599).

\section{Ülkelerin Küresel İnovasyon Endeks Değerlerinin ve İnovasyon Etkililik Performanslarının Tespiti}

Avrupa Birliği ülkelerinin küresel inovasyon endeks değerleri 2019 yılı için belirtilen rapor kapsamında elde edilmiştir. Söz konusu ülkelere ait küresel inovasyon endeksi, inovasyon girdi dizini ile inovasyon çıktı dizi değerlerinin aritmetik ortalaması ile tespit edilmektedir. Bunun yanında ülkelere ait inovasyon etkililiği ise inovasyon çıtı alt dizininin inovasyon girdi alt dizinine oranlanmasıyla hesaplanmıştır. Bu kapsamda araştırmaya konu olan ülkelerin küresel inovasyon endeks ve inovasyon etkililiği performans değerleri Tablo 5'de belirtilmiştir.

Tablo 5: Ülkelere Ait KİE, KİGAE, KİÇAE ve Etkililik Değerleri

\begin{tabular}{|c|c|c|c|c|c|c|}
\hline ÜLKELER & KIE & KİE-Sıralama & KİGAE & KİÇAE & ETKİLILİK & ETKİLILİK-Sıralama \\
\hline Almanya & 58,2 & 6 & 65,3 & 51,1 & 0,7825 & 8 \\
\hline Avusturya & 50,9 & 10 & 62,8 & 39,1 & 0,623 & 24 \\
\hline Belçika & 50,2 & 11 & 60,7 & 39,6 & 0,652 & 21 \\
\hline Bulgaristan & 40,3 & 25 & 48,1 & 32,6 & 0,678 & 18 \\
\hline Çekya & 49,4 & 13 & 55,4 & 43,4 & 0,7833 & 7 \\
\hline Danimarka & 58,4 & 5 & 69,3 & 47,5 & 0,685 & 17 \\
\hline Estonya & 50 & 12 & 56,1 & 43,8 & 0,781 & 9 \\
\hline Finlandiya & 59,8 & 4 & 68 & 51,6 & 0,759 & 11 \\
\hline Fransa & 54,2 & 8 & 63,5 & 45 & 0,709 & 14 \\
\hline GKRK & 48,3 & 15 & 55,5 & 41,1 & 0,741 & 12 \\
\hline Hirvatistan & 37,8 & 27 & 47,4 & 28,3 & 0,597 & 27 \\
\hline Hollanda & 61,4 & 2 & 65,4 & 57,5 & 0,879 & 1 \\
\hline İngiltere & 61,3 & 3 & 68,2 & 54,4 & 0,798 & 5 \\
\hline İrlanda & 56,1 & 7 & 62,1 & 50,1 & 0,807 & 4 \\
\hline İspanya & 47,9 & 16 & 57,3 & 38,4 & 0,67 & 20 \\
\hline İsveç & 63,7 & 1 & 70,4 & 56,9 & 0,808 & 3 \\
\hline İtalya & 46,3 & 17 & 54,7 & 37,9 & 0,693 & 15 \\
\hline Letonya & 43,2 & 21 & 51,3 & 35,2 & 0,686 & 16 \\
\hline Litvanya & 41,5 & 23 & 50,6 & $32,, 3$ & 0,638 & 22 \\
\hline Lüksemburg & 53,5 & 9 & 57,7 & 49,2 & 0,853 & 2 \\
\hline Macaristan & 44,5 & 20 & 50,3 & 38,7 & 0,769 & 10 \\
\hline Malta & 49 & 14 & 54,6 & 43,4 & 0,795 & 6 \\
\hline Polonya & 41,3 & 24 & 51 & 31,7 & 0,622 & 25 \\
\hline Portekiz & 44,6 & 19 & 54,7 & 34,6 & 0,633 & 23 \\
\hline Romanya & 28 & 28 & 45,5 & 28 & 0,615 & 26 \\
\hline Slovakya & 42 & 22 & 48,5 & 35,6 & 0,734 & 13 \\
\hline Slovenya & 45,5 & 18 & 54,1 & 36,4 & 0,673 & 19 \\
\hline Yunanistan & 38,9 & 26 & 50,2 & 27,6 & 0,55 & 28 \\
\hline
\end{tabular}

KİE: Küresel İnovasyon Endeksi

KİGAE: Küresel İnovasyon Girdi Alt Endeksi

KIÇAE: Küresel İnovasyon Çıktı Alt Endeksi

Tablo 5'e göre, küresel inovasyon endeksi en fazla olan ilk üç ülke sırasıyla İsveç, Hollanda ve İngiltere olduğu tespit edilmiştir. Tablo 5'e göre, Bulgaristan, Yunanistan, Hirvatistan ve Romanya'nın birbirleri arasındaki küresel inovasyon endeks farkları az çıkmış olup, söz konusu 
ülkelerin diğer ülkeler ile olan küresel inovasyon endeks farkları, diğer ülkelerin birbirleri ve Bulgaristan, Yunanistan, Hırvatistan ve Romanya ile olan küresel inovasyon endeks farklarından fazla çıkmıştır. Özellikle Hollanda, Lüksemburg ve İsveç, İrlanda ve İngiltere'nin inovasyon etkililik değerleri 0,800 'değerinin üstünde olması, söz konusu ülkelerin inovasyon etkililik performanslarının yüksek olduğunu göstermektedir.

\section{OCRA Yöntemi ile Ülkelerin İnovasyon Etkinlik Performanslarının Tespiti}

OCRA yöntemi kapsamında ilk olarak Tablo 2'de belirtilen karar matrisi, karar matrisindeki kriterlerin maksimum ile minimum değerleri ve Tablo 4'te belirtilen Entropi yöntemi kapsamında ülkelere göre inovasyon bileşenlerinin önemlilik dereceleri (ağırlık katsayıları) üzerinden ölçeklendirilmemiş girdi ve çıktı tercih endeks değerleri tespit edilir. Bunun için Tablo 2 'de belirtilen karar matrisi değerleri üzerinden her bir girdi ve çıktı endeksine ait maksimum ve minimum değerlerin belirtilmesi gerekmektedir. Bu kapsamda tespit edilen ölçeklendirilmemiş girdi ve çıktı tercih endeks değerleri Tablo 6 'da belirtilmiştir.

Tablo 6: Ölçeklendirilmemiş Girdi ve Çıktı Tercih Endeksi

\begin{tabular}{|c|c|c|c|c|c|c|c|}
\hline \multirow{2}{*}{ ÜLKELER } & \multicolumn{5}{|c|}{ GİRDİLER } & \multicolumn{2}{|c|}{ ÇIKTILAR } \\
\hline & G1 & G2 & G3 & G4 & G5 & Ç1 & Ç2 \\
\hline Almanya & 0,015383 & 0,000969 & 0,020197 & 0,05765 & 0,055601 & 0,165733 & 0,132939 \\
\hline Avusturya & 0,016238 & 0,015505 & 0,021904 & 0,076867 & 0,065671 & 0,072033 & 0,087136 \\
\hline Belçika & 0,024784 & 0,0407 & 0,033851 & 0,068584 & 0,064357 & 0,096043 & 0,070938 \\
\hline Bulgaristan & 0,054055 & 0,158925 & 0,043807 & 0,094427 & 0,124775 & 0,040994 & 0,044685 \\
\hline Çekya & 0,032049 & 0,096906 & 0,036127 & 0,078192 & 0,098506 & 0,113612 & 0,096632 \\
\hline Danimarka & 0,004059 & 0,001454 & 0,009387 & 0,03015 & 0,042467 & 0,128839 & 0,127353 \\
\hline Estonya & 0,025425 & 0,103204 & 0,021619 & 0,07753 & 0,114705 & 0,067933 & 0,144668 \\
\hline Finlandiya & 0 & 0 & 0,019912 & 0,061958 & 0,021452 & 0,179789 & 0,12456 \\
\hline Fransa & 0,02222 & 0,036824 & 0,019343 & 0,043403 & 0,06786 & 0,12064 & 0,107245 \\
\hline GKRK & 0,028416 & 0,13373 & 0,037549 & 0,058976 & 0,092815 & 0,098386 & 0,08546 \\
\hline Hurvatistan & 0,051919 & 0,134699 & 0,049781 & 0,099397 & 0,151043 & 0,007028 & 0,029045 \\
\hline Hollanda & 0,005769 & 0,053298 & 0,020766 & 0,058976 & 0,022328 & 0,219026 & 0,153047 \\
\hline İngiltere & 0,013888 & 0,019866 & 0,01337 & 0 & 0,063482 & 0,188573 & 0,147461 \\
\hline İrlanda & 0,017306 & 0,072679 & 0,007965 & 0,070903 & 0,056915 & 0,19033 & 0,097749 \\
\hline İspanya & 0,033117 & 0,079463 & 0,017068 & 0,054668 & 0,131779 & 0,074961 & 0,077641 \\
\hline İsveç & 0,007478 & 0,006299 & 0 & 0,046054 & 0 & 0,219026 & 0,145786 \\
\hline İtalya & 0,039099 & 0,087215 & 0,027593 & 0,081506 & 0,116456 & 0,084916 & 0,061442 \\
\hline Letonya & 0,03504 & 0,1284 & 0,05291 & 0,071566 & 0,137471 & 0,018155 & 0,094956 \\
\hline Litvanya & 0,037604 & 0,131307 & 0,049497 & 0,083162 & 0,134844 & 0 & 0,080992 \\
\hline Lüksemburg & 0,027562 & 0,105143 & 0,029584 & 0,096415 & 0,035462 & 0,104242 & 0,169804 \\
\hline Macaristan & 0,047005 & 0,108534 & 0,046652 & 0,100391 & 0,122586 & 0,107756 & 0,049154 \\
\hline Malta & 0,039313 & 0,129853 & 0,022757 & 0,102048 & 0,060855 & 0,043922 & 0,163101 \\
\hline Polonya & 0,042731 & 0,107565 & 0,043523 & 0,093102 & 0,133093 & 0,038066 & 0,036865 \\
\hline Portekiz & 0,025212 & 0,076071 & 0,034989 & 0,086807 & 0,137909 & 0,031624 & 0,075965 \\
\hline Romanya & 0,056619 & 0,166193 & 0,041532 & 0,108674 & 0,154108 & 0,034552 & 0 \\
\hline Slovakya & 0,0438 & 0,150204 & 0,042385 & 0,094759 & 0,145351 & 0,056221 & 0,063118 \\
\hline Slovenya & 0,024143 & 0,081401 & 0,043238 & 0,107349 & 0,108138 & 0,036895 & 0,091046 \\
\hline Yunanistan & 0,056405 & 0,067349 & 0,049497 & 0,08515 & 0,159361 & 0,004099 & 0,024018 \\
\hline
\end{tabular}


Araştırmaya konu olan ülkelerin inovasyon etkinliğini tespit etmek için girdi ve çıktı alt endekslerine göre ülkelere ait ölçeklendirilmiş genel tercih endeks değerleri hesaplanır. Bunun için ilk olarak Tablo 6'da belirtilen ölçeklendirilmemiş girdi ve çıktı tercih endeks değerleri üzerinden ölçeklendirilmiş girdi tercih endeksi ve ölçeklendirilmiş çıktı tercih endeks değerlerinin tespit edilmesi gerekmektedir. Devamında ölçeklendirilmiş girdi tercih endeksi ve ölçeklendirilmiş çıktı tercih endeks değerleri üzerinden ise ölçeklendirilmiş genel tercih endeksi (ülkelerin inovasyon etkinliği) hesaplanır. Bu kapsamda ülkelere göre ölçeklendirilmiş girdi ve çıktı endeks değerleri, ölçeklendirilmemiş ve ölçeklendirilmiş genel tercih endeks değerleri (ülkelerin inovasyon etkinlik performans değerleri) ile ölçeklendirilmiş genel tercih endeks değerlerinin sıralaması Tablo 7'de gösterilmiştir.

Tablo 7: Ölçeklendirilmiş Genel Tercih Endeks (İnovasyon Performans Etkinliği) Değerleri

\begin{tabular}{|c|c|c|c|c|c|c|c|}
\hline \multirow{2}{*}{$\begin{array}{c}\text { Ülkeler } \\
\text { Almanya }\end{array}$} & \multicolumn{2}{|c|}{$\begin{array}{l}\text { Ölçeklendirilmiş } \\
\text { Girdi Tercih } \\
\text { Endeksi }\end{array}$} & \multicolumn{2}{|c|}{$\begin{array}{l}\text { Ölçeklendirilmiş } \\
\text { Çıktı Tercih } \\
\text { Endeksi }\end{array}$} & \multirow{2}{*}{$\begin{array}{c}\text { Genel Tercih } \\
\text { Endeksi } \\
\text { (Ölçeklendirilmemiş) } \\
0,360524311\end{array}$} & \multirow{2}{*}{$\begin{array}{c}\text { Genel Tercih } \\
\text { Endeksi } \\
\text { (Ölçeklendirilmiş) } \\
0,104763331\end{array}$} & \multirow{2}{*}{$\begin{array}{r}\text { Sira } \\
20\end{array}$} \\
\hline & 0,149801 & 0,08997 & 0,298672 & 0,270554 & & & \\
\hline Avusturya & 0,196184 & 0,136354 & 0,159169 & 0,131051 & 0,267404617 & 0,011643637 & 27 \\
\hline Belçika & 0,232277 & 0,172446 & 0,166981 & 0,138863 & 0,311309742 & 0,055548762 & 26 \\
\hline Bulgar. & 0,47599 & 0,416159 & 0,085679 & 0,057562 & 0,473720342 & 0,217959362 & 6 \\
\hline Çekya & 0,34178 & 0,281949 & 0,210244 & 0,182126 & 0,464075161 & 0,208314181 & 8 \\
\hline Dan. & 0,087518 & 0,027687 & 0,256192 & 0,228074 & 0,25576098 & 0 & 28 \\
\hline Estonya & 0,342484 & 0,282653 & 0,212602 & 0,184484 & 0,467136617 & 0,211375637 & 7 \\
\hline Finlandiya & 0,103322 & 0,043492 & 0,304349 & 0,276231 & 0,319722512 & 0,063961532 & 25 \\
\hline Fransa & 0,189651 & 0,12982 & 0,227884 & 0,199767 & 0,329587072 & 0,073826092 & 24 \\
\hline GKRK & 0,351486 & 0,291655 & 0,183846 & 0,155729 & 0,447383454 & 0,191622474 & 10 \\
\hline Hirvat. & 0,486839 & 0,427008 & 0,036073 & 0,007955 & 0,434962898 & 0,179201919 & 12 \\
\hline Hollanda & 0,161136 & 0,101305 & 0,372073 & 0,343955 & 0,445260473 & 0,189499493 & 11 \\
\hline İngiltere & 0,110605 & 0,050774 & 0,336034 & 0,307917 & 0,358690609 & 0,102929629 & 21 \\
\hline İrlanda & 0,225768 & 0,165938 & 0,288079 & 0,259961 & 0,425898674 & 0,170137694 & 14 \\
\hline İspanya & 0,316095 & 0,256264 & 0,152601 & 0,124484 & 0,380747808 & 0,124986828 & 18 \\
\hline İsveç & 0,059831 & 0 & 0,364811 & 0,336694 & 0,336693665 & 0,080932685 & 23 \\
\hline İtalya & 0,351869 & 0,292038 & 0,146359 & 0,118241 & 0,410279155 & 0,154518175 & 15 \\
\hline Letonya & 0,425387 & 0,365556 & 0,113111 & 0,084993 & 0,450548718 & 0,194787738 & 9 \\
\hline Litvanya & 0,436414 & 0,376583 & 0,080992 & 0,052874 & 0,429457036 & 0,173696056 & 13 \\
\hline Lüksem. & 0,294166 & 0,234335 & 0,274046 & 0,245928 & 0,480263449 & 0,22450247 & 3 \\
\hline Macar. & 0,425167 & 0,365337 & 0,15691 & 0,128792 & 0,494128617 & 0,238367637 & 2 \\
\hline Malta & 0,354826 & 0,294995 & 0,207023 & 0,178906 & 0,473900886 & 0,218139907 & 4 \\
\hline Polonya & 0,420014 & 0,360183 & 0,074931 & 0,046814 & 0,406997053 & 0,151236073 & 16 \\
\hline Portekiz & 0,360987 & 0,301156 & 0,107589 & 0,079471 & 0,380627312 & 0,124866332 & 19 \\
\hline Romanya & 0,527126 & 0,467295 & 0,034552 & 0,006434 & 0,473729187 & 0,217968207 & 5 \\
\hline Slovakya & 0,476498 & 0,416668 & 0,119338 & 0,091221 & 0,507888223 & 0,252127243 & 1 \\
\hline Slovenya & 0,364269 & 0,304438 & 0,127941 & 0,099823 & 0,4042615 & 0,14850052 & 17 \\
\hline Yunanistan & 0,417763 & 0,357932 & 0,028118 & 0 & 0,357932011 & 0,102171031 & 22 \\
\hline
\end{tabular}

Tablo 7'ye göre, ülkelerin inovasyon performans etkinliği en fazla olan ilk 3 ülke Slovakya, Macaristan ve Lüksemburg olmuştur. Tablo 7 değerlendirildiğinde, Avusturya, Danimarka, Finlandiya, Fransa, İsveç ve Yunanistan ülkelerinin diğer ülkeler ile olan inovasyon 
performans etkinliği farkları, diğer ülkelerin birbirleri ve Avusturya, Danimarka, Finlandiya, Fransa, İsveç ve Yunanistan ülkeleri ile olan inovasyon etkinliği değerleri farklarından fazla çıkmıştır. Ayrıca Tablo 7'ye göre, Malta-Romanya-Bulgaristan, Letonya-GKRK, Litvanya-İrlanda, İspanya-Portekiz ve Almanya-İngiltere ülkelerinin inovasyon etkinlik değerleri birbirlerine çok yakın değerdedirler.

\section{EATWIOS Yöntemi ile Ülkelerin İnovasyon Verimlilik Performanslarının Tespiti}

EATWIOS yönteminde ilk olarak normalizasyon matrisinin oluşturulması için Tablo 2'de belirtilen karar matrisi değerleri üzerinden kriterlerin (inovasyon girdi ve çıktı alt dizinlere bağlı bileşenlerin) ülkelere ait değerlerin karelerinin toplamlarının karakök değerleri hesaplanır. Buna göre tespit edilen kriterlerin (inovasyon girdi ve çıktı alt dizinlere bağlı bileşenlerin) ülkelere ait değerlerin karelerinin toplamları ve ülkelere ait değerlerin karelerinin toplamlarının karakök değerleri Tablo 8'de belirtilmiştir.

Tablo 8: Karar Matrisindeki Girdi ve Çıktı Bileşen Değerlerinin Karelerinin Toplam ve Toplam Karelerin Karekökleri

\begin{tabular}{cccccccc}
\hline \multirow{2}{*}{ İslemler } & \multicolumn{3}{c}{ GÍRDİLER } & \multicolumn{3}{c}{ ÇIKTILAR } \\
& G1 & G2 & G3 & G4 & G5 & Ç1 & Ç2 \\
\hline Karelerin Top. & 179765,8 & 63560,66 & 96020,48 & 81650,04 & 66004,59 & 48004,03 & 51893,12 \\
Karakök & 423,988 & 252,1124 & 309,8717 & 285,7447 & 256,9136 & 219,0982 & 227,8006 \\
\hline
\end{tabular}

EATWIOS yönteminde her bir ülkeye karşılık gelen inovasyon girdi ve çıktı alt dizinlerini oluşturan bileşenlerin mesafe ölçümleri hesaplanmalıdır. Bunun için Tablo 2'de belirtilen karar matrisinde bulunan değerlerin normalize edilmesi gerekmektedir. Buna bağlı olarak EATWIOS yöntemi kapsamında normalize edilen değerler Tablo 9'da belirtilmiştir. 
Avrupa Birliği Ülkelerinin İnovasyon Etkililik, Etkinlik ve Verimlilik Performanslarının... 2355

Tablo 9: EATWIOS Yöntemi Kapsamında Hesaplanan Normalize Matrisi

\begin{tabular}{|c|c|c|c|c|c|c|c|}
\hline \multirow{2}{*}{ ÜLKELER } & \multicolumn{5}{|c|}{ GİRDİLER } & \multicolumn{2}{|c|}{ ÇIKTILAR } \\
\hline & G1 & G2 & G3 & G4 & G5 & Ç1 & Ç2 \\
\hline Almanya & 0,000481 & 0,000994 & 0,000646 & 0,000718 & 0,00085 & 0,001098 & 0,000956 \\
\hline Avusturya & 0,000478 & 0,000947 & 0,000639 & 0,000647 & 0,000815 & 0,000765 & 0,000798 \\
\hline Belçika & 0,000456 & 0,000865 & 0,000596 & 0,000677 & 0,00082 & 0,00085 & 0,000742 \\
\hline Bulgaristan & 0,00038 & 0,000481 & 0,000559 & 0,000582 & 0,000611 & 0,000654 & 0,000651 \\
\hline Çekya & 0,000437 & 0,000683 & 0,000587 & 0,000642 & 0,000701 & 0,000912 & 0,000831 \\
\hline Danimarka & 0,00051 & 0,000993 & 0,000685 & 0,000819 & 0,000895 & 0,000967 & 0,000937 \\
\hline Estonya & 0,000454 & 0,000662 & 0,00064 & 0,000644 & 0,000645 & 0,00075 & 0,000996 \\
\hline Finlandiya & 0,000521 & 0,000997 & 0,000647 & 0,000702 & 0,000968 & 0,001148 & 0,000927 \\
\hline Fransa & 0,000463 & 0,000878 & 0,000649 & 0,00077 & 0,000808 & 0,000937 & 0,000867 \\
\hline GKRK & 0,000447 & 0,000563 & 0,000582 & 0,000713 & 0,000721 & 0,000858 & 0,000792 \\
\hline Hirvatistan & 0,000386 & 0,00056 & 0,000537 & 0,000563 & 0,00052 & 0,000533 & 0,000597 \\
\hline Hollanda & 0,000506 & 0,000824 & 0,000644 & 0,000713 & 0,000965 & 0,001287 & 0,001025 \\
\hline İngiltere & 0,000485 & 0,000933 & 0,000671 & 0,000931 & 0,000823 & 0,001179 & 0,001006 \\
\hline İrlanda & 0,000476 & 0,000761 & 0,00069 & 0,000669 & 0,000845 & 0,001185 & 0,000834 \\
\hline İspanya & 0,000434 & 0,000739 & 0,000657 & 0,000729 & 0,000586 & 0,000775 & 0,000765 \\
\hline İsveç & 0,000501 & 0,000977 & 0,00072 & 0,000761 & 0,001042 & 0,001287 & 0,001 \\
\hline İtalya & 0,000419 & 0,000714 & 0,000619 & 0,00063 & 0,000639 & 0,00081 & 0,000709 \\
\hline Letonya & 0,000429 & 0,000581 & 0,000526 & 0,000666 & 0,000567 & 0,000573 & 0,000825 \\
\hline Litvanya & 0,000423 & 0,000571 & 0,000538 & 0,000623 & 0,000576 & 0,000508 & 0,000777 \\
\hline Lüksemburg & 0,000449 & 0,000656 & 0,000611 & 0,000574 & 0,00092 & 0,000879 & 0,001083 \\
\hline Macaristan & 0,000398 & 0,000645 & 0,000549 & 0,00056 & 0,000618 & 0,000892 & 0,000667 \\
\hline Malta & 0,000418 & 0,000576 & 0,000636 & 0,000554 & 0,000832 & 0,000665 & 0,00106 \\
\hline Polonya & 0,000409 & 0,000648 & 0,00056 & 0,000587 & 0,000582 & 0,000644 & 0,000624 \\
\hline Portekiz & 0,000455 & 0,00075 & 0,000592 & 0,00061 & 0,000565 & 0,000621 & 0,000759 \\
\hline Romanya & 0,000373 & 0,000458 & 0,000568 & 0,000529 & 0,000509 & 0,000631 & 0,000497 \\
\hline Slovakya & 0,000407 & 0,00051 & 0,000564 & 0,000581 & 0,000539 & 0,000708 & 0,000715 \\
\hline Slovenya & 0,000458 & 0,000733 & 0,000561 & 0,000534 & 0,000668 & 0,00064 & 0,000811 \\
\hline Yunanistan & 0,000374 & 0,000779 & 0,000538 & 0,000616 & 0,000491 & 0,000523 & 0,00058 \\
\hline
\end{tabular}

Ülkelerin inovasyon verimlilik değerlerinin tespiti için devamında Tablo 9'da belirtilen değerler üzerinden her bir ülkeye karşılık gelen inovasyon girdi ve çıktı alt dizinlerine ait bileşenlerin mesafe ölçüm değerleri ile söz konusu mesafe ölçüm değerleri üzerinden mesafe ölçüm değerlerinin ağırlıklandırılmış değerleri hesaplanır. Buna göre, mesafe ölçümleri ve ağırlıklandırılmış mesafe ölçüsü değerleri Tablo 10'da sunulmuştur. 
Tablo 10: Mesafe Ölçümü ve Mesafe Ölçümünün Ağırlıklandırılması

\begin{tabular}{|c|c|c|c|c|c|c|c|}
\hline \multicolumn{8}{|c|}{ MESAFE ÖLÇÜMÜ } \\
\hline \multirow{2}{*}{ Ülkeler } & \multicolumn{5}{|c|}{ GİRDİLER } & \multicolumn{2}{|c|}{ ÇIKTILAR } \\
\hline & G1 & $\mathrm{G} 2$ & G3 & G4 & G5 & Ç1 & Ç2 \\
\hline Almanya & 1,000107 & 1,000536 & 1,00012 & 1,000189 & 1,000359 & 0,99996 & 0,999997 \\
\hline Avusturya & 1,000105 & 1,000489 & 1,000114 & 1,000118 & 1,000324 & 0,999958 & 0,99995 \\
\hline Belçika & 1,000083 & 1,000407 & 1,00007 & 1,000148 & 1,000329 & 0,999935 & 0,999868 \\
\hline Bulgaristan & 1,000007 & 1,000024 & 1,000033 & 1,000053 & 1,00012 & 0,999859 & 0,999484 \\
\hline Çekya & 1,000064 & 1,000225 & 1,000061 & 1,000113 & 1,000211 & 0,999917 & 0,999685 \\
\hline Danimarka & 1,000137 & 1,000535 & 1,000159 & 1,00029 & 1,000405 & 0,999989 & 0,999995 \\
\hline Estonya & 1,000081 & 1,000205 & 1,000115 & 1,000115 & 1,000155 & 0,999934 & 0,999665 \\
\hline Finlandiya & 1,000147 & 1,00054 & 1,000121 & 1,000173 & 1,000477 & 1 & 1 \\
\hline Fransa & 1,00009 & 1,00042 & 1,000123 & 1,000241 & 1,000317 & 0,999942 & 0,99988 \\
\hline GKRK & 1,000073 & 1,000105 & 1,000056 & 1,000184 & 1,00023 & 0,999926 & 0,999566 \\
\hline Hirvatistan & 1,000012 & 1,000102 & 1,000011 & 1,000034 & 1,000029 & 0,999865 & 0,999563 \\
\hline Hollanda & 1,000132 & 1,000367 & 1,000118 & 1,000184 & 1,000474 & 0,999985 & 0,999827 \\
\hline İngiltere & 1,000111 & 1,000475 & 1,000145 & 1,000402 & 1,000332 & 0,999964 & 0,999935 \\
\hline İrlanda & 1,000102 & 1,000304 & 1,000165 & 1,00014 & 1,000355 & 0,999955 & 0,999764 \\
\hline İspanya & 1,000061 & 1,000282 & 1,000131 & 1,0002 & 1,000095 & 0,999914 & 0,999742 \\
\hline İsveç & 1,000128 & 1,000519 & 1,000194 & 1,000231 & 1,000551 & 0,999981 & 0,99998 \\
\hline İtalya & 1,000046 & 1,000256 & 1,000093 & 1,0001 & 1,000148 & 0,999898 & 0,999717 \\
\hline Letonya & 1,000056 & 1,000123 & 1 & 1,000137 & 1,000076 & 0,999909 & 0,999583 \\
\hline Litvanya & 1,00005 & 1,000113 & 1,000012 & 1,000094 & 1,000085 & 0,999902 & 0,999574 \\
\hline Lüksemburg & 1,000076 & 1,000198 & 1,000085 & 1,000045 & 1,000429 & 0,999928 & 0,999659 \\
\hline Macaristan & 1,000025 & 1,000187 & 1,000023 & 1,000031 & 1,000127 & 0,999878 & 0,999648 \\
\hline Malta & 1,000045 & 1,000118 & 1,00011 & 1,000024 & 1,000341 & 0,999898 & 0,999578 \\
\hline Polonya & 1,000036 & 1,00019 & 1,000034 & 1,000058 & 1,000091 & 0,999889 & 0,999651 \\
\hline Portekiz & 1,000082 & 1,000293 & 1,000066 & 1,000081 & 1,000074 & 0,999934 & 0,999753 \\
\hline Romanya & 1 & 1 & 1,000042 & 1 & 1,000018 & 0,999853 & 0,99946 \\
\hline Slovakya & 1,000033 & 1,000052 & 1,000039 & 1,000051 & 1,000048 & 0,999886 & 0,999512 \\
\hline Slovenya & 1,000085 & 1,000275 & 1,000035 & 1,000005 & 1,000177 & 0,999937 & 0,999736 \\
\hline Yunanistan & 1,000001 & 1,000321 & 1,000012 & 1,000087 & 1 & 0,999853 & 0,999781 \\
\hline \multicolumn{8}{|c|}{ MESAFE ÖLÇÜMÜNÜN AĞIRLIKLANDIRILMASI } \\
\hline Almanya & 0,143379 & 0,141073 & 0,143671 & 0,143159 & 0,1419 & 0,142888 & 0,144109 \\
\hline Avusturya & 0,143379 & 0,141067 & 0,14367 & 0,143149 & 0,141895 & 0,142888 & 0,144103 \\
\hline Belçika & 0,143376 & 0,141055 & 0,143664 & 0,143153 & 0,141896 & 0,142885 & 0,144091 \\
\hline Bulgaristan & 0,143365 & 0,141001 & 0,143659 & 0,143139 & 0,141866 & 0,142874 & 0,144035 \\
\hline Çekya & 0,143373 & 0,141029 & 0,143663 & 0,143148 & 0,141879 & 0,142882 & 0,144064 \\
\hline Danimarka & 0,143384 & 0,141073 & 0,143677 & 0,143173 & 0,141906 & 0,142892 & 0,144109 \\
\hline Estonya & 0,143376 & 0,141026 & 0,14367 & 0,143148 & 0,141871 & 0,142884 & 0,144062 \\
\hline Finlandiya & 0,143385 & 0,141074 & 0,143671 & 0,143157 & 0,141917 & 0,142894 & 0,14411 \\
\hline Fransa & 0,143377 & 0,141057 & 0,143672 & 0,143166 & 0,141894 & 0,142886 & 0,144093 \\
\hline GKRK & 0,143374 & 0,141012 & 0,143662 & 0,143158 & 0,141882 & 0,142883 & 0,144047 \\
\hline Hirvatistan & 0,143366 & 0,141012 & 0,143655 & 0,143137 & 0,141853 & 0,142875 & 0,144047 \\
\hline
\end{tabular}




\begin{tabular}{cccccccc}
\hline Hollanda & 0,143383 & 0,141049 & 0,143671 & 0,143158 & 0,141916 & 0,142892 & 0,144085 \\
İngiltere & 0,14338 & 0,141065 & 0,143675 & 0,143189 & 0,141896 & 0,142889 & 0,144101 \\
İrlanda & 0,143379 & 0,14104 & 0,143677 & 0,143152 & 0,141899 & 0,142887 & 0,144076 \\
İspanya & 0,143373 & 0,141037 & 0,143673 & 0,143161 & 0,141863 & 0,142882 & 0,144073 \\
İsveç & 0,143382 & 0,141071 & 0,143682 & 0,143165 & 0,141927 & 0,142891 & 0,144107 \\
İtalya & 0,14337 & 0,141034 & 0,143667 & 0,143146 & 0,14187 & 0,142879 & 0,144069 \\
Letonya & 0,143372 & 0,141015 & 0,143654 & 0,143152 & 0,14186 & 0,142881 & 0,14405 \\
Litvanya & 0,143371 & 0,141014 & 0,143656 & 0,143145 & 0,141861 & 0,14288 & 0,144048 \\
Lüksemburg & 0,143375 & 0,141026 & 0,143666 & 0,143138 & 0,14191 & 0,142884 & 0,144061 \\
Macaristan & 0,143367 & 0,141024 & 0,143657 & 0,143136 & 0,141867 & 0,142876 & 0,144059 \\
Malta & 0,14337 & 0,141014 & 0,14367 & 0,143135 & 0,141897 & 0,142879 & 0,144049 \\
Polonya & 0,143369 & 0,141024 & 0,143659 & 0,14314 & 0,141862 & 0,142878 & 0,144059 \\
Portekiz & 0,143376 & 0,141039 & 0,143663 & 0,143144 & 0,14186 & 0,142884 & 0,144074 \\
Romanya & 0,143364 & 0,140998 & 0,14366 & 0,143132 & 0,141852 & 0,142873 & 0,144032 \\
Slovakya & 0,143369 & 0,141005 & 0,143659 & 0,143139 & 0,141856 & 0,142878 & 0,14404 \\
Slovenya & 0,143376 & 0,141036 & 0,143659 & 0,143133 & 0,141874 & 0,142885 & 0,144072 \\
Yunanistan & 0,143364 & 0,141043 & 0,143656 & 0,143144 & 0,141849 & 0,142873 & 0,144078 \\
Ağırlık Katsay1ları & 0,143364 & 0,140998 & 0,143654 & 0,143132 & 0,141849 & 0,142894 & 0,14411 \\
\hline
\end{tabular}

Ülkelerin inovasyon verimlilik değerleri, Tablo $10^{\prime}$ da belirtilen ağılıklandırılmış mesafe ölçüm değerleri üzerinden hesaplanmaktadır. Bu kapsamda ülkelere ait inovasyon verimlilik performans değerleri ve bu değerlerin sıralaması Tablo 11'de gösterilmiştir.

Tablo 11. Ülkelerin İnovasyon Verimlilik Değerleri ve Değerlerin Sıralaması

\begin{tabular}{cccccccccc}
\hline Ülkeler & Girdi & Çıktı & Verimlilik & Sıra & Ülkeler & Girdi & Çıtı & Verimlilik & Sıra \\
\hline Almanya & 0,71318 & 0,28699 & 0,402418 & 5 & İspanya & 0,7131 & 0,28695 & 0,402401 & 13 \\
Avusturya & 0,71315 & 0,28699 & 0,402421 & 2 & İsveç & 0,71322 & 0,28699 & 0,402394 & 20 \\
Belçika & 0,71314 & 0,28697 & 0,402409 & 7 & İtalya & 0,71308 & 0,28694 & 0,402403 & 11 \\
Bulgaristan & 0,71303 & 0,2869 & 0,40238 & 26 & Letonya & 0,71305 & 0,28693 & 0,402398 & 15 \\
Çekya & 0,71309 & 0,28694 & 0,402397 & 17 & Litvanya & 0,71304 & 0,28692 & 0,402398 & 16 \\
Danimarka & 0,71321 & 0,287 & 0,402406 & 8 & Lüksemburg & 0,71311 & 0,28694 & 0,402382 & 25 \\
Estonya & 0,71309 & 0,28694 & 0,402397 & 18 & Macaristan & 0,71305 & 0,28693 & 0,402405 & 10 \\
Finlandiya & 0,7132 & 0,287 & 0,402415 & 6 & Malta & 0,71308 & 0,28692 & 0,402375 & 28 \\
Fransa & 0,71316 & 0,28697 & 0,402401 & 14 & Polonya & 0,71305 & 0,28693 & 0,402406 & 9 \\
GKRK & 0,71308 & 0,28693 & 0,402377 & 27 & Portekiz & 0,71308 & 0,28695 & 0,402421 & 3 \\
Hırvatistan & 0,71302 & 0,28692 & 0,402401 & 12 & Romanya & 0,713 & 0,2869 & 0,402388 & 24 \\
Hollanda & 0,71317 & 0,28697 & 0,402392 & 22 & Slovakya & 0,71302 & 0,28691 & 0,402392 & 21 \\
İngiltere & 0,7132 & 0,28698 & 0,402394 & 19 & Slovenya & 0,71307 & 0,28695 & 0,40242 & 4 \\
İrlanda & 0,71314 & 0,28696 & 0,40239 & 23 & Yunanistan & 0,71305 & 0,2869 & 0,402425 & 1 \\
\hline
\end{tabular}

Tablo 11'e göre, ülkelerin inovasyon performans verimliliği en fazla olan ilk 3 ülke Yunanistan, Avusturya ve Portekiz olmuştur. Ayrıca Tablo 11'e göre, ülkelerin inovasyon verimlilik değerleri arasında belirgin farklılıklar bulunmamaktadır. Bunun yanında Tablo 5, Tablo 7 ve Tablo 11 bütünleşik olarak değerlendirildiğinde, Fransa'nın inovasyon etkililik ile verimlilik (14. Sira), Hırvatistan'ın inovasyon etkinlik ile verimlilik (12. Sira) ve İtalya'nın inovasyon etkililik ile etkinlik değerlerinin (15. Sıra) sıralamaları aynı çıkmıştır. Bunların dışında diğer 
ülkelerin inovasyon etkililik, etkinlik ve verimlilik değerlerinin sıralamaları birbirinden farklı olduğu tespit edilmiştir.

\section{Sonuç ve Tartışma}

Çalışmada ilk olarak inovasyon kavramının tanımı, kapsamı, çeşitleri, ülkeler için önemi ve ülkelerin inovasyon performanslarını ölçen endeksler, küresel inovasyon endeksi ve küresel inovasyon endeksi ile ilgili literatürde bulunan araştırmalar hakkında açıklamalar yapılmıştır.

Çalışmanın amaçları kapsamında 2019 yılı için Avrupa Birliği ülkelerine göre inovasyon girdi ve çıktı alt bileşenlerinin önemlilik dereceleri (ağırlık katsayıları) ile Avrupa Birliği ülkelerinin etkililik, etkinlik ve verimlilik performans değerlerini tespit edilmiştir.

Ülkelere göre, inovasyon girdi ve çıktı alt dizinlerine ait bileşenlerin önemlilik dereceleri (ağırlık katsayıları) yaratıcılık çıktısı (Ç2), altyapı (G3), kurumlar (G1), pazar gelişmişliği (G4), bilgi ve teknoloji çıktısı (Ç1), iş gelişmişliği (G5) ve beşeri sermaye ve araştırma (G2) olarak sıralanmıştır. Avrupa Birliği ülkelerine göre, inovasyon bileşenlerinin önemlilik derecelerinin birbirlerine çok yakın değerde olduğu tespit edilmiştir. Bu durum, Avrupa Birliği ülkelerinin inovasyon bileşenlerine genel anlamda eşit önem verdiğini ve buna bağlı olarak Avrupa Birliği ülkelerine göre inovasyon bileşenlerinin birbirlerini tamamladığı değerlendirilmiştir. Araştırmada ülkelere göre inovasyon çıktı bileşenlerinin ortalama önemlilik derecesi, inovasyon girdi bileşenlerinin ortalama önemlilik derecesinden fazla olduğu tespit edilmiştir. Dolayısıyla Avrupa Birliği ülkelerinin inovasyon temellerini (girdilerini) tamamladığını ve buna bağlı olarak Avrupa Birliği ülkelerinin sonuç odaklı (çıktılar) inovasyon faaliyetlerine, sebep odaklı (girdiler) inovasyon faaliyetlere göre daha çok yoğunlaştıkları değerlendirilmiştir. Bu durum ayrıca Avrupa Birliği ülkelerinin inovasyon oluşturacağı katma değerden ve olumlu sonuçlardan anlamlı olarak faydalanmak istediklerini göstermektedir.

Ülkelerin inovasyon etkililik değerleri değerlendirildiğinde, inovasyon etkililiği en fazla olan ilk üç ülke İsveç, Hollanda ve İngiltere olarak sıralanmıştır. Dolayısıyla inovasyon etkililiği fazla olan ülkelerin diğer ülkelere göre hangi inovasyon girdinin/girdilerinin hangi inovasyon çıktısını/çıktılarını daha çok optimal düzeyde sağlayacağının analizlerini diğer ülkelere göre daha çok verimli olarak yaptığı değerlendirilebilir.

Araştırma sonucuna göre, ülkelerin inovasyon etkinlik performans değerleri en fazla olan ilk üç ülke Slovakya, Macaristan ve Lüksemburg olarak tespit edilmiştir. İnovasyon etkinliği fazla olan ülkelerin inovasyon amaçlarının doğru belirlenmesi ve inovasyon konusunda doğru işlerin yapılması düzeyi diğer ülkelere göre fazla olduğu değerlendirilmiştir. Böylelikle bu durum, inovasyon etkinliği fazla olan ülkelerin, kendi inovasyon potansiyellerini ve yeteneklerini diğer ülkelere göre daha çok tanıdıklarını ve bildiklerini göstermektedir.

Bulgulara göre, ülkelerin verimlilik performans değerleri en fazla olan ilk 3 ülke Yunanistan, Avusturya ve Portekiz olduğu tespit edilmiştir. İnovasyon verimliliği fazla olan ülkelerin inovasyon amaçlarına ulaşma ve inovasyon konusunda işlerin doğru yapılması düzeyinin diğer ülkelere göre fazla olduğu değerlendirilebilir. Dolayısıyla inovasyon verimliliği fazla olan ülkelerin diğer ülkelere göre inovasyon planlamaları ile inovasyon uygulamaları birbirleri ile daha çok tutarlı olduğunu düşünülebilir.

Araştırmada ayrıca Fransa'nın inovasyon etkililik ile verimlilik, Hırvatistan'ın inovasyon etkinlik ile verimlilik ve İtalya'nın inovasyon etkililik ile etkinlik performans değerlerinin sıralamalarının aynı olduğu tespit edilmiştir. Anılan ülkeler haricinde diğer ülkelerin inovasyon etkililik, etkinlik ve verimlilik performans değerlerinin sıralamaları birbirinden farklı olduğu tespit edilmiştir. Dolayısıyla araştırmada araştırmaya dahil olan ülkelerin inovasyon etkililik, etkinlik ve verimlilik değerlerinin sıralamaları birbirinden farklı olması, inovasyon kapsamında etkililik, 
etkinlik ve verimlilik kavramlarının birbiriyle ilişkili, fakat söz konusu kavramların birbirinden farklı olduğunu göstermektedir.

Bu çalışma 2019 y1lı için Avrupa Birliğine üye 28 ülkenin inovasyon etkililik, etkinlik, verimlilik performans değerlerinin ve onların sıralaması ile küresel inovasyon girdi ve çıktı alt dizinlerine ait bileşenlerin önemlilik derecelerinin (ağırlık katsayılarının) belli sayısal yöntemlerle tespit edilmesi kapsamında araştırmacılar için bir veri seti niteliği kazanmıştır. Ülkelerin inovasyon performansları sadece küresel inovasyon endeks değerleri kapsamında değil, söz konusu ülkelere ait küresel inovasyon endeks girdi ve çıktı alt dizinlerine ait bileşenler aracıllğı ile ülkelerin inovasyon etkililiği, etkinliği ve verimliliği tespit edilerek ülkelerin ayrı olarak inovasyon performansları çok boyutlu ve ayrıntılı olarak değerlendirilebilir. Böylelikle ülkelerin inovasyon problemlerinin kaynă̆ kolayca tespit edilebilip, problemin kaynağına yönelik spesifik çözümler oluşturulabilir. Bunun yanında ülkelerin çok boyutlu olarak inovasyon etkililiklerinin, etkinliklerinin ve verimliliklerinin tespit edilmesi ile ülkelerin inovasyon konusunda geleceğe yönelik metotlarının, stratejilerinin, uygulamalarının ve yönetimlerinin daha sağlıklı olması sağlanabilir. Ülkelerin inovasyon etkililik, etkinlik, verimlilik performanslarının ve küresel inovasyon girdi ve çıktı alt dizinlerine ait bileşenlerinin önemlilik derecelerinin (ă̆ırlık katsayılarının) tespit edilmesinde daha fazla çok kriterli karar verme teknikleri uygulanarak söz konusu tekniklere göre tespit edilen nicelik değerlerinin tutarlılıkları ve farklılıkları tespit edilip ülkelerin inovasyon konusunda performanslarının ölçümünde standart sayısal yöntemler geliştirilebilir. Ayrıca inovasyon girdi ve çıktı alt dizinlerini oluşturan bileşenlerin sayısı daha kapsamlı olarak fazlalaştırılabilir veya her ülkeye özgü farklı bileşenler oluşturulabilir.

\section{Kaynakça}

Ay Türkmen, M., Aynaoğlu, Y. (2017). "Küresel rekabet endeksi göstergelerin küresel inovasyon üzerine etkisi." Business \& Management Studies: An International Journal, 5(4): 257-282.

Benavente, D., Dutta, S., Wuncsh Vincent, S. (2012). The Global Innovation Index 2012: Stronger Innovation Linkages for Global Growth. The Global Innovation Index 2012.

Burmaoğlu, S. (2012). "Ulusal inovasyon göstergeleri ile ulusal lojistik performansı arasındaki ilişki: AB ülkeleri üzerine bir araştırma." Ege Akademik Bakış, 12(2): 193-208.

Cantwell, J. (2003). Innovation and competitiveness. R. R. Nelson, \& D. Fagerberg içinde, handbook of innovation. Oxford: Oxford University Press, 1-31.

Clark, J., Guy, K. (2010). "Innovation and competitiveness: a review." Technology Analysis \& Strategic Management, 10(3): 363-395.

Cornell University, INSEAD, WIPO. (2019). Global Inovation Index Report.

Gaberli, Ü. (2019). Hizmetler Sektöründe Yenilik Turizimde Inovasyonun Doğası. B. Uyan, M. Çakır içinde, Ikktisadi ve Sosyal Yönleri ile Ínovasyon. Ankara: Iksad Publications, 117-140.

Giunchiglia, F. (2013). Innovatione Sociale La Fuora Frontiora. Department Information Engineering and Computer Science, DISI. Trento: University of Trento .

Hancıoğlu, Y. (2016). "Küresel inovasyon endeksini oluşturan inovasyon girdi ve çıktı göstergeleri arasındaki ilişkinin kanonik korelasyon ile incelenmesi: OECD örneği." A $\dot{I} B \ddot{U}$ Sosyal Bilimler Enstitüsü Dergisi, 16(4): 131-157.

INSEAD. (2007). The World's Top Innovators. France: The World Business/INSEAD Global Innovation Index. 
Jankowska, B., Matysek, A., Jedrych, K., Mroczek, D. (2017). "Efficiency of national innovation systems-Poland and Bulgaria in the context of the global innovation index." Comparative Economic Research, 20(3): 77-94.

Jintana, J., Limcharoen, A., Patsopa, Y., "Ramingwong, S. (2020). Innovation ecosystem of ASEAN countries." Amoziana Investiga, 9(28): 356-364.

Karaata, E. S. (2012). İnovasyonun Ölçümünde Yeni Arayışlar. İstanbul: TÜSİAD-Sabanc1 Üniversitesi Rekabet Forumu.

Khedhaouria, A., Roy, T. (2017). "Configurational conditions of national innovation capability: a fuzzy set analysis approach." Technological Forecasting and Social Change, 120: 48-58.

Kijek, A., Kijek, T. (2010). "The analysis of innovation input-output relationships." Comparative Economic, 13(1): 93-106.

Kılıç, F. (2018). Açık inovasyon kavramı ve etkileri üzerine bir uygulama. Yayımlanmamış yüksek lisans tezi, Pamukkale Üniversitesi Sosyal Bilimler Enstitüsü, Denizli.

Kofler, I., Marcher, A., Anesi, F., Pechlaner, H., Streifeneder, T. (2018). Rafforzare le Reti d'innovazione Regionali:Prospettive per un Alto Adige Competitivo. Bozen: Eurac Research.

Layos, J. M., Peña, P. J. (2010). "Can innovation save us? understanding the role of innovation in mitigating the covid-19 pandemic in ASEAN-5 economies." SSRN: https://ssrn.com/abstract $=3591428$ or http://dx.doi.org/10: 1-9.

Mytelka , L., Farinelli, F. (2000). Local Clusters, Innovation Systems and Sustained Competitiveness. Maastricht: United Nations University, Institute for New Technologies.

OECD, Eurostat. (2005). Oslo Klavuzu: Yenilik Verilerinin Toplanması ve Yorumlanması İçin İlkeler. Ankara: TÜBİTAK, 1-117

Özbek, H., Atik, H. (2013). "İnovasyon göstergeleri bakımından Türkiye'nin Avrupa Birliği ülkeleri arasındaki yeri." Erciyes Üniversitesi İktisadi ve İdari Bilimler Fakültesi Dergisi (42): 193-210.

Porter, M., van der Linde, C. (1995). "Toward a new conception of the environmentcompetitiveness relationship." Journal of Economic Perspectives, 9(4): 97-118.

Savaşc1, A. (2017). Küresel İnovasyon Endeksi. Adana: Adana Sanayi Odas1.

Sohn, S. Y., Kim, D. H. (2016). "Re-Evaluation of global innovation index evaluation of global innovation index." Technology Analysis \& Strategic Manegement, (4): 492-505.

Soylu, A., Ceylan, S., Özdipçiner, N. S. (2019). "Turizmde deneyim inovasyonu: doğu ekspresi örneği." SETSCI Conference Proceedings, 4(8): 231-235.

Süt, E., Çetin, A. K. (2018). "İnovasyon göstergesi olarak inovasyon endeksleri." Uluslararası Turizm, İsletme, Ekonomi Dergisi, 2(2): 299-309.

Şahinli, M. A., Kılınç, E. (2013). "İnovasyon ve inovasyon göstergeleri: AB ülkeleri ve Türkiye karşılaştırılması." Selçuk Üniversitesi İktisadi ve İdari Bilimler Fakültesi Sosyal ve Ekonomik Araştırmalar Dergisi, 13(25): 329-355.

Şimşit, Z. T., Arıŏglu Akan, Ö. M., Saniye, Ü., Fırat, O. (2014). Küresel Rekabet ve İnovasyon Çerçevesinde Türkiye'nin Lojistik Performansının Değerlendirilmesi. 3. Ulusal Lojistik ve Tedarik Zinciri Kongeresi, Trabzon, 1-10. 
Avrupa Birliği Ülkelerinin İnovasyon Etkililik, Etkinlik ve Verimlilik Performanslarının... 2361

Wagner, M. (2009). "The links of sustainable competitiveness and innovation with openness and user integration: an empirical analysis." International Journal of Innovation and Sustainable Development, 4(4): 314-329.

www.katalog.tdk.gov.tr

www.izto.org.tr

Yıldız, Y. K. (2018). "İnovasyon endekslerine göre Türkiye'nin durumu ve sağlik sektörüne etkileri." Adnan Menderes Üniversitesi Sağlık Bilimleri Fakültesi Dergisi, 2(2): 107-117. 